\title{
Insect trace fossils in aeolian deposits and calcretes from the Canary Islands: Their ichnotaxonomy, producers, and palaeoenvironmental significance
}

\author{
Jorge F. Genise ${ }^{\text {a,* }}$, Ana M. Alonso-Zarza ${ }^{\text {b }}$, Mariano Verde ${ }^{c}$, Alfonso Meléndez d \\ a CONICET, División Icnología, Museo Argentino de Ciencias Naturales, Av. Angel, Gallardo 470, 1405 Buenos Aires, Argentina \\ b Departamento de Petrologia y Geoquímica, FaC. CC. Geológicas, IGE (CSIC, UCM), Universidad Complutense de Madrid, C/Jose Antonio Novais, 2, 28040 Madrid, Spain \\ c SNI-ANII De partamento de Evolución de Cuencas, Facultad de Ciencias, Universidad de in República, Montevideo, Uruguay \\ a De partamento de Ciencias de ia Tierra, Universidad de Zaragoza, C/Pedro Cerbuna 12, 50009, Zaragoza, Spain
}

Keywords:

Insect trace fossils

Rebuffoichnus gunche isp. nov.

Coleopteran pupation chambers

Canary Islands

Aeolian deposits

Calcretes

Palaeonvironments

\begin{abstract}
A B S T R A C T
Insect trace fossils from Canary Islands have been known and discussed since the beginnings of the last century. The most common and widespread morphologies have been tentatively referred to the ichnogenera Celliforma, Palmiraichnus or Rebuffoichnus and attributed to bees, coleopterans, and locusts until now. Herein they are included in a new single ichnospecies: Rebuffoichnus guanche isp. nov., which can be distinguished from other ichnospecies by the presence of an antechamber. R. guanche are considered herein as coleopteran (Curculionidae or Scarabaeidae) pupation chambers. This is supported by the mostly horizontal orientation in soils, ellipsoid shape, dispersion of sizes, and particularly the internal surface of the wall chamber that is completely smoothed, even in both extremes. In addition, it is supported by the finding of one adult weevil in a similar trace fossil and palaeoenvironment of Australia. All these characters argue against their assignation neither, to egg pods of a locust species nor to bee cells, the latter also contradicted by the lack of spiral closure. The wall of $R$. guanche shows the same petrological features of those of the palaeosol in which specimens are found. In those specimens found in aeolian deposits, the wall is composed of sand grains similar to those found in the dunes or sand sheets. The diversity of microfabrics found in calcretes is higher and depends on the calcrete hostrock and the degree of development of the calcretes. In poorly developed calcretes the trace fossils reflect very well the calcrete hostrock, whereas in more developed ones they usually show peloidal/ooidal or laminar microfabrics. These similarities indicate that, in contrast to some previous reports, insects utilised as building material that of the surrounding soil, as expectable for a coleopteran pupation chamber. Lower numbers of $R$. guanche are recorded in calcretes from the western Canary Islands, where no aeolian deposits are present, in contrast to the high densities in the aeolian deposits of the eastern Islands. Coleopterans would first colonise thin soils with calcretes developed on basaltic or sedimentary rocks in young islands and later colonise dunes as they appear when the islands aged. The widespread presence of calcretes, aeolian deposits, and trace fossils in the easternmost and older Canary Islands is driven by both the geological evolution of the Islands and climatic conditions. Both the calcretes and pupation chambers formed during the relatively wetter periods within otherwise prevailing arid to semiarid conditions.
\end{abstract}

\section{Introduction}

The record and interpretation of Canary Island insect trace fossils started early in the last century (Aranda Millán, 1909; HernándezPacheco, 1909; Bravo, 1954; Machado, 1976; Báez and Bacallado, 1984; Rothe, 1986; Petit-Maire et al., 1987). These authors attributed such trace fossils to bees, particularly to anthophorids, as Ellis and Ellis-Adams (1993), Edwards and Meco (2000), Alonso-Zaiza and Silva (2002), and von Suchodoletz et al. (2009). The first to call attention to other possible producers such as coleopterans or even lepidopterans were Genise and Edwards (2003). Recently, Meco et al. (2010,

\footnotetext{
* Corresponding author. Tel.: +54 $1149819282 \times 148$.

E-mail address: jgenise@macn.gov.ar (J.F. Genise)
}

2011) attributed these trace fossils to locusts, whereas Mas and Ripoll (2010) described similar ones from the Balearic Islands.

The ichnotaxonomical identification of these trace fossils has been inconclusive and is still pending. Ellis and Ellis-Adams (1993), Edwards and Meco (2000), and Alonso-Zatza and Silva (2002) attributed such structures to the ichnogenus Celliforma, in accordance with the original broad definition of this ichnogenus for all supposed fossil bee cells. Genise and Edwards (2003) analysed the possibility of attributing some of the trace fossils to Rebuffoichnus or Palmiraichnus. Recently, a new and different type of race fossil from the islands was recorded and attributed to Palmiraichnus (La Roche et al., 2010). Another matter of debate has been the provenance of material used to build chambers. Edwards and Meco (2000) and Genise and Edwards (2003) suggested that the building material was brought from areas far from the nesting 
site, whereas Alonso-Zarza and Silva (2002) concluded that it came from the same nesting soil. Insect trace fossils, calcretes and aeolian deposits occur very commonly in the easternmost Canary Islands (Gran Canaria, Fuerteventura, and Ianzarote), whereas they are scarce in the western, more humid islands. The palaeoenvironmental influence on the distribution of calcretes, aeolian deposits, and trace fossils is reflected in their occurrence throughout the islands, but also in the predominant formation of calcretes and trace fossils in semi-arid periods, whereas in the more arid periods, aeolian sedimentation prevailed (Alonso-Zarza and Silva, 2002; Meco, 2008; Meco et al., 2011).

The objectives of this contribution are: 1) to establish an ichnotaxonomy for these Canary Island trace fossils, 2) to identify their producers, 3 ) to ascertain the provenance of the material used to build traces, 4) to obtain palaeoenvironmental inferences provided by trace fossils, their producers, and the deposits where they are found, 5) to decipher optimum conditions (environments) for the initial development of the insect communities and their subsequent colonisation of wider island areas, and 6) to discuss the possible relationship of the distribution of traces and calcretes with the geological evolution of the Canary Island Archipelago.

\section{Geologic setting}

The Canary Islands constitute a volcanic archipelago situated near the African coast. The archipelago lies on the continental margin of the Africa plate, on an oceanic crust of early Jurassic age (Schmincke et al., 1998; Steiner et al., 1998; Carracedo et al., 2002; Ancochea et al., 2004). The age of emergence of the islands decreases from $E$ to W. The ages are: Lanzarote and Fuerteventura, 20-21 Ma; Gran Canaria, 10-15 Ma; Tenerife, 11-12 Ma; La Gomera, 1.7 Ma and Ia Palma and El Hierro, 1.2 Ma. These ages, together with their alignment in agreement with the ages, strongly suggest that the origin of the Islands is related with the activity of a hot spot (Carracedo et al., 1998, 2002, 2008; Hoernle and Carracedo, 2009).

The older islands, Ianzarote and Fuerteventura situated closer to Africa, show less relief, with maximum heights of 807 min Fuerteventura. They are in a senile evolutive stage dominated by erosive and sedimentary morphologies. Pliocene to Holocene aeolian deposits, calcretes, and insect trace fossil accumulations were intensively developed in Ianzarote, Fuerteventura, and Gran Canaria. Towards the west the islands are younger with more abrupt relief, and heights up to $3716 \mathrm{~m}$ in El Teide (Tenerife). In the westem Islands there is a dominance of constructive volcanic morphologies, indicating a juvenile stage. Aeolian deposits, calcretes, and trace fossils are scarce in these more humid islands (IGME, 2005, 2006).

In the older islands sands composed of bioclastic and volcanic grains were deposited in aeolian dunes at different times during the Pleistocene (Meco, 2008). The bioclastic grains came from marine deposits of the Quaternary, marine platforms. There are up two 12 levels of marine terraces situated from $+1 \mathrm{~m}$ to $+65-70 \mathrm{~m}$ above the present sea level (Zazo et al., 2002). These marine deposits were reworked by prevailing winds transporting sand grains, giving place to the formation of large dune fields in the easternmost Canary Islands. Calcretes were formed since the Pliocene in the relatively less arid periods (Criado, 1988; Alonso-Zarza and Silva, 2002). Palaeoclimatic trends for the eastern Canary Islands have been established on the basis of previous pedological, sedimentological, and palaeoecological studies (Petit-Maire et al., 1987; Danmati, 1997; Zazo et al., 1997; Meco et al., 2011). The altemation between glacial and interglacial periods occurred throughout the Pleistocene, resulted in changes in sea level and also in the formation of various sediments inland. The colder-glacial periods favoured the deposition of sand dunes, whereas during the interglacial periods the widespread development of soils, including calcretes, took place. Present-day climatic conditions reflect the scarcity of water, and predominant arid conditions within Lanzarote and Fuerteventura. Their climate is controlled by the cold Canary Current, which reduces precipitation and causes high temperatures equivalent to those recorded in the Westem Sahara (Danmati, 1997). Both islands have a mean annual precipitation of $105 \mathrm{~mm}$.

\section{Sedimentary context of trace fossil occurrences}

The trace fossils described here appear in two sedimentary contexts: aeolian deposits and calcrete profiles. Twenty seven outcrops have been studied (Fig. 1, Table 1) in Fuerteventura and Lanzarote. Herein are included the descriptions of six selected outcrops (two aeolian sequences and four calcrete profiles) that contain race fossils (Figs. 2,3).

\subsection{Aeolian deposits}

\subsubsection{Sobrado de la Palma}

This locality comprises a large area covered by aeolian deposits, middle Pleistocene in age (IGME, 2006). These sands contain at least three palaeosol levels with trace fossils (Fig. 2A). The studied section is more than $6 \mathrm{~m}$ thick and is composed of several beds of well-sorted medium-to-fine bioclastic sands. The beds contain abundant trace fossils, gastropods, and rhizoliths that are found mostly at the top of the beds and are sparse at their bases (Fig. 3). The sands show low-angle cross-stratification and diffuse lamination. These structures are only visible when the deposits contain few traces and rhizoliths.

\subsubsection{Jable C}

This locality is also situated in a large sandy aeolian area, of Pleistocene s.l. age (IGME, 2005). The outcrop is $1 \mathrm{~m}$ thick and is composed of medium-sized well-sorted bioclastic sands (Figs. 2B, 3).

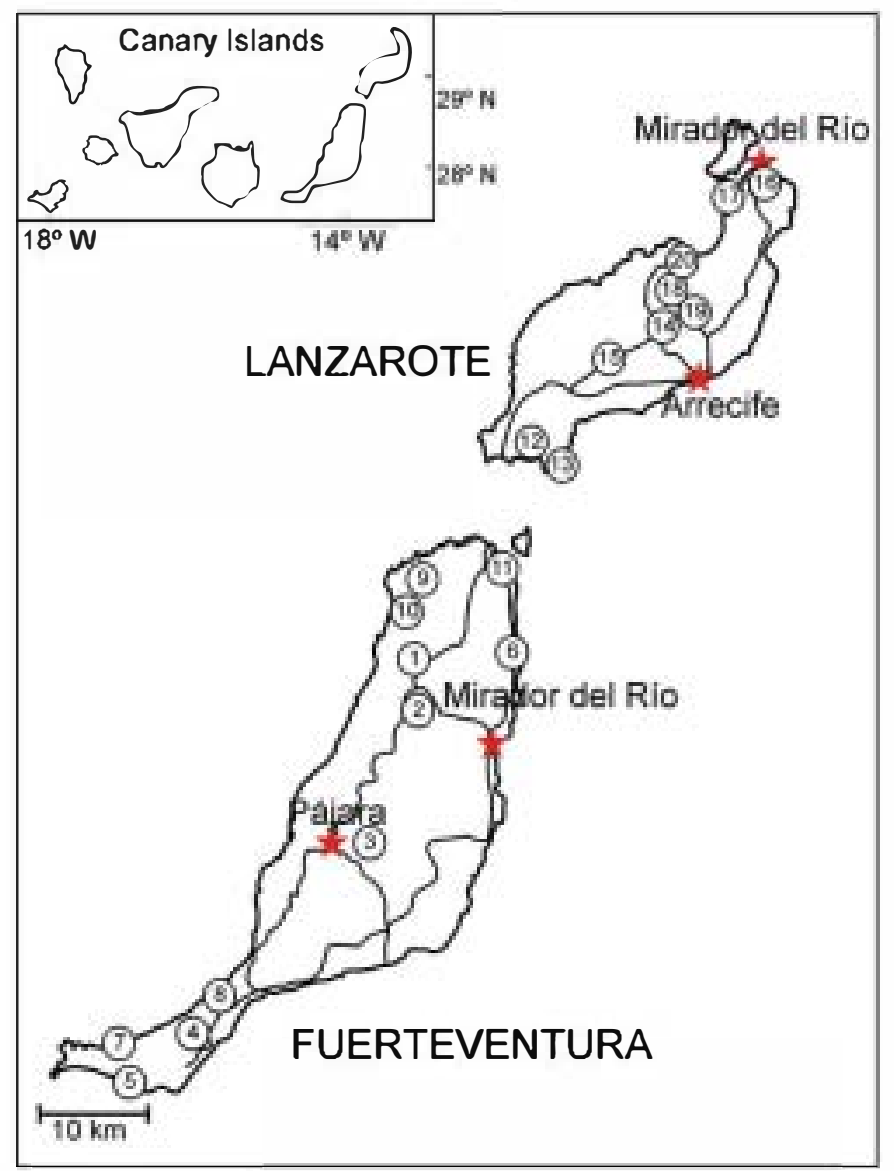

Fig. 1. Situation of the different studied localities in both Islands: Fuerteventura and Ianzarote. The names of the localities are shown in Table 1. 
Table 1

Studied localities of Ianzarote and Fuerteventura.

\begin{tabular}{|c|c|c|c|c|c|c|c|}
\hline \multicolumn{4}{|l|}{ Fuerteventura } & \multicolumn{4}{|l|}{ Lanzarote } \\
\hline \multicolumn{2}{|l|}{ Calcretes } & \multicolumn{2}{|l|}{ Aeolian } & \multicolumn{2}{|l|}{ Calcretes } & \multicolumn{2}{|l|}{ Aeolian } \\
\hline \multirow{2}{*}{ 1. Tefía } & $28^{\bullet} 30^{\prime} 19.68^{\prime \prime} \mathrm{N}$ & 7. Cofete & $28^{\bullet} 5^{\prime} 58.71^{\prime \prime} \mathrm{N}$ & 12. Playa Blanca & $28^{\circ} 52^{\prime} 23.83^{\prime \prime} \mathrm{N}$ & 18. Taо & $29^{\circ} 2^{\prime} 29.88^{\prime \prime} \mathrm{N}$ \\
\hline & $14^{\circ} 0^{\prime} 15.23^{\prime \prime} \mathrm{W}$ & & $14^{\circ} 25^{\prime} 12.95^{\prime \prime} \mathrm{W}$ & & $13^{\bullet} 49^{\prime} 0.49^{\prime \prime} \mathrm{W}$ & & $13^{\bullet} 36^{\prime} 55.61^{\prime \prime} \mathrm{W}$ \\
\hline \multirow[t]{2}{*}{ 2. Ampuyenta } & $28^{\circ} 28^{\prime} 7.60^{\prime \prime} \mathrm{N}$ & 8. Istmo de la Pared & $28^{\bullet} 10^{\prime} 13.39^{\prime \prime} \mathrm{N}$ & 13. Punta Papagayo & $28^{\bullet} 50^{\prime} 33.25^{\prime \prime} \mathrm{N}$ & 14. San Bartolomé (B) & $29^{\circ} 1^{\prime} 5.75^{\prime \prime} \mathrm{N}$ \\
\hline & $13^{\circ} 59^{\prime} 53^{\prime \prime} \mathrm{W}$ & & $14^{\circ} 14^{\prime} 39.88^{\prime \prime} \mathrm{W}$ & & $13^{\circ} 47^{\prime} 7.71^{\prime \prime} \mathrm{W}$ & & $13^{\circ} 34^{\prime} 31.04^{\prime \prime} \mathrm{W}$ \\
\hline \multirow[t]{2}{*}{ 3. Tiscamanita } & $28^{\bullet} 21^{\prime} 26.60^{\prime \prime} \mathrm{N}$ & 6. Parque del Holandés (A) & $28^{\bullet} 36^{\prime} 52.62^{\prime \prime} \mathrm{N}$ & 14. San Bartolomé (A) & $28^{\bullet} 59^{\prime} 41.07^{\prime \prime} \mathrm{N}$ & 19. Teguise & $29^{\circ} 2^{\prime} 5.73^{\prime \prime} \mathrm{N}$ \\
\hline & $14^{*} 1^{\prime} 58.06^{\prime \prime} \mathrm{W}$ & & $13^{\circ} 50^{\prime} 53.08^{\prime \prime} \mathrm{W}$ & & $13^{\bullet} 35^{\prime} 49.96^{\prime \prime} \mathrm{W}$ & & $13^{\bullet} 34^{\prime} 42.27^{\prime \prime} \mathrm{W}$ \\
\hline \multirow[t]{2}{*}{ 4. Casas de Pecenescal } & $28^{\circ} 7^{\prime} 34.59^{\prime \prime} \mathrm{N}$ & 9. Sobrado de la Palma & $28^{\bullet} 39^{\prime} 56.02^{\prime \prime} \mathrm{N}$ & 15. Mácher (A) & $28^{\bullet} 56^{\prime} 47.15^{\prime \prime} \mathrm{N}$ & 20. Jable (A) & $29^{\circ} 5^{\prime} 11.86^{\prime \prime} \mathrm{N}$ \\
\hline & $14^{\circ} 17^{\prime} 6.15^{\prime \prime} \mathrm{W}$ & & $13^{\circ} 56^{\prime} 11.63^{\prime \prime} \mathrm{W}$ & & $13^{\circ} 41^{\prime} 39.51^{\prime \prime} \mathrm{W}$ & & $13^{\circ} 34^{\prime} 14.73^{\prime \prime} \mathrm{W}$ \\
\hline \multirow[t]{2}{*}{ 5. Cementerio de Jandía } & $28^{\bullet} 3^{\prime} 29.07^{\prime \prime} \mathrm{N}$ & 10. Cañada Melián & $28^{\bullet} 39^{\prime} 52^{\prime \prime} \mathrm{N}$ & 15. Mácher (B) & $28^{\bullet} 56^{\prime} 29.21^{\prime \prime} \mathrm{N}$ & 20. Jable (B) & $29^{\circ} 5^{\prime} 26.20^{\prime \prime} \mathrm{N}$ \\
\hline & $14^{\bullet} 21^{\prime} 59.71^{\prime \prime} \mathrm{W}$ & & $13^{\bullet} 57^{\prime} 21^{\prime \prime} \mathrm{W}$ & & $13^{\circ} 42^{\prime} 34.44^{\prime \prime} \mathrm{W}$ & & $13^{\circ} 34^{\prime} 22.02^{\prime \prime} \mathrm{W}$ \\
\hline \multirow[t]{6}{*}{ 6. Parque del Holandés (B) } & $28^{\bullet} 36^{\prime} 37^{\prime \prime} \mathrm{N}$ & 11. Corrale jo (A) & $28^{\bullet} 43^{\prime} 33.53^{\prime \prime} \mathrm{N}$ & 16. Mirador del Río & $29^{\circ} 12^{\prime} 43.86^{\prime \prime} \mathrm{N}$ & 20. Jable (C) & $29^{\circ} 5^{\prime} 44.23^{\prime \prime} \mathrm{N}$ \\
\hline & $13^{\circ} 50^{\prime} 50^{\prime \prime} \mathrm{W}$ & & $13^{\circ} 51^{\prime} 10.88^{\prime \prime} \mathrm{W}$ & & $13^{\circ} 29^{\prime} 1.68^{\prime \prime} \mathrm{W}$ & & $13^{\circ} 34^{\prime} 25.38^{\prime \prime} \mathrm{W}$ \\
\hline & & 11. Corrale jo (B) & $28^{\circ} 43^{\prime} 3.79^{\prime \prime} \mathrm{N}$ & 17.Yé & $29^{\circ} 12^{\prime} 1.08^{\prime \prime} \mathrm{N}$ & & \\
\hline & & & $13^{\circ} 51^{\prime} 2.31^{\prime \prime} \mathrm{W}$ & & $13^{\circ} 29^{\prime} 29.03^{\prime \prime} \mathrm{W}$ & & \\
\hline & & 11. Corrale jo (C) & $28^{\circ} 40^{\prime} 20.38^{\prime \prime} \mathrm{N}$ & & & & \\
\hline & & & $13^{\circ} 50^{\prime} 10.60^{\prime \prime} \mathrm{W}$ & & & & \\
\hline
\end{tabular}

The base of the bed shows diffuse planar high-angle cross-stratification and a large concentration of trace fossils and gastropods. All these features, together with the presence of burrows and large rhizoliths, have disturbed the stratification. Towards the top, the sand is more massive and the traces and gastropods occur more sparsely.

\subsection{Petrology of the aeolian deposits}

The aeolian sands are composed of grains whose mean size ranges from $0.2 \mathrm{~mm}$ to $0.5 \mathrm{~mm}$ (Fig. $4 \mathrm{~A}$ and C). The grains are bioclasts, quartz, fragments of volcanic rocks, and a few olivines and pyroxenes. Amongst the bioclasts, the most common are: foraminifera, mollusks, bryozoans, red algae, ostracods and equinoderms. Shells preserve the original aragonite mineralogy. Space between the grains is either empty or filled partially by micrite or microspar (Fig. 4A). Fine fibrous cements and coarse calcite spar occur very rarely. These relatively homogeneous sands show two main noticeable features. One of them is the occurrence of irregular, tubular-to-spheroidal masses of micritic carbonate amongst grains. These masses are up to $2 \mathrm{~cm}$ across and contain alveolar septal structures and microspar microtubules (Fig. 4B). The other noticeable feature is the presence of micrite coatings on the grains (Fig. $4 \mathrm{C}$ ). The coatings are mostly constructive, but in some cases the micrite, penetrate grains and may contain some clay and iron oxides. The coatings are relatively irregular and in some cases, show micritic filaments, which may connect different coatings.

\subsection{Calcrete profiles}

\subsubsection{Tefia}

The Tefia calcrete profile is developed on the surface of a wide alluvial fan, cut by a network of recent gullies. The geomorphological situation indicates an upper Pleistocene age for this profile (Alonso-Zarza and Silva, 2002). The profile is developed on coarse gravels composed mostly of volcanic fragments. It is $1.75 \mathrm{~m}$ thick and consists of three main horizons (Figs. 2C, 3). The lower one consists of massive and powder limestones that include sparse gravel clasts. Locally it shows prismatic and laminar structure. Trace fossils are not very common and are randomly distributed. The intermediate horizon is formed by alternations offine red mudstone deposits with thin and irregular carbonate laminae. The red mudstones contain abundant calcified rootlets and traces. The latter are also common in the laminar carbonate. The upper horizon is composed of a lower bed of red mudstones with trace fossils, rootlets, and an upper laminar and irregular bed of carbonate that shows anticline-like structures at the top. Trace fossils occur within the whole upper horizon. They are loose in the red mudstones and hard, impregnated by carbonate in the topmost one.

\subsubsection{Parque del Holandés}

The profile $1.40 \mathrm{~m}$ thick was developed on well-sorted medium sands, apparently massive, and contains carbonate rhizoliths and trace fossils densely grouped in some levels (Figs. 2D, 3, 9A). The age of the sand unit that contains this profile is late Pleistocene (IGME, 2006). The sands consist mostly of bioclasts and scarce volcanic clasts. The most outstanding feature of this profile is the occurrence of different horizons containing trace fossils that are completely coated by carbonate, forming pisoliths, in which the nucleus is a race fossil (Alonso-Zarza et al., 2012; Fig. 2D). The horizons containing the trace fossils and/or pisoliths are either sandy or limestone. Calcified rootlets and thin laminar and irregular layers of carbonate are also common.

\subsubsection{Macher}

The profile is very complex, and is developed directly on black weathered basalts and includes some interbedded lapilli layers. The basalts correspond to the Pleistocene Series III of Fiister et al. (1968a, $1968 \mathrm{~b})$, whose radiometric age is $1.2-0.24 \mathrm{Ma}$, so the most probable age for the profile formation is middle Pleistocene (Alonso-Zarza and Silva, 2002). The basalts are cut by a dense network of cracks filled by white and laminated carbonate (Fig. 2E). The profile (1.5 $\mathrm{m}$ thick) is composed of multi storey and various small-scale sequences of red mudstones with rootlets (or more rarely lapilli) in their base and laminar calcrete horizons at their top. These sequences are not very continuous laterally so they overlap in some cases. Thin laminar and irregular carbonate layers occur also in red mudstones (Fig. 3). Both red mudstones and the laminar carbonates include a large number of race fossils with varying degrees of carbonate impregnation. The topmost also shows anticline-like structures.

\subsubsection{Mirador del Río}

The profile ( $1.25 \mathrm{~m}$ thick) is formed on red mudstones that contain sparse gravel clasts and sand grains (Figs. 2F, 3). The mudstones correspond to a Pleistocene clastic unit that includes pyroclasts (IGME, 2005). The lower horizon of mudstones is impregnated by carbonate forming a relative massive horizon. The thicker horizon of red mudstones with sparse carbonate impregnation and large rhizoliths is overlain by thin carbonate laminae interbedded between the mudstones. The upper horizon contains trace fossils and is red and sandy. 

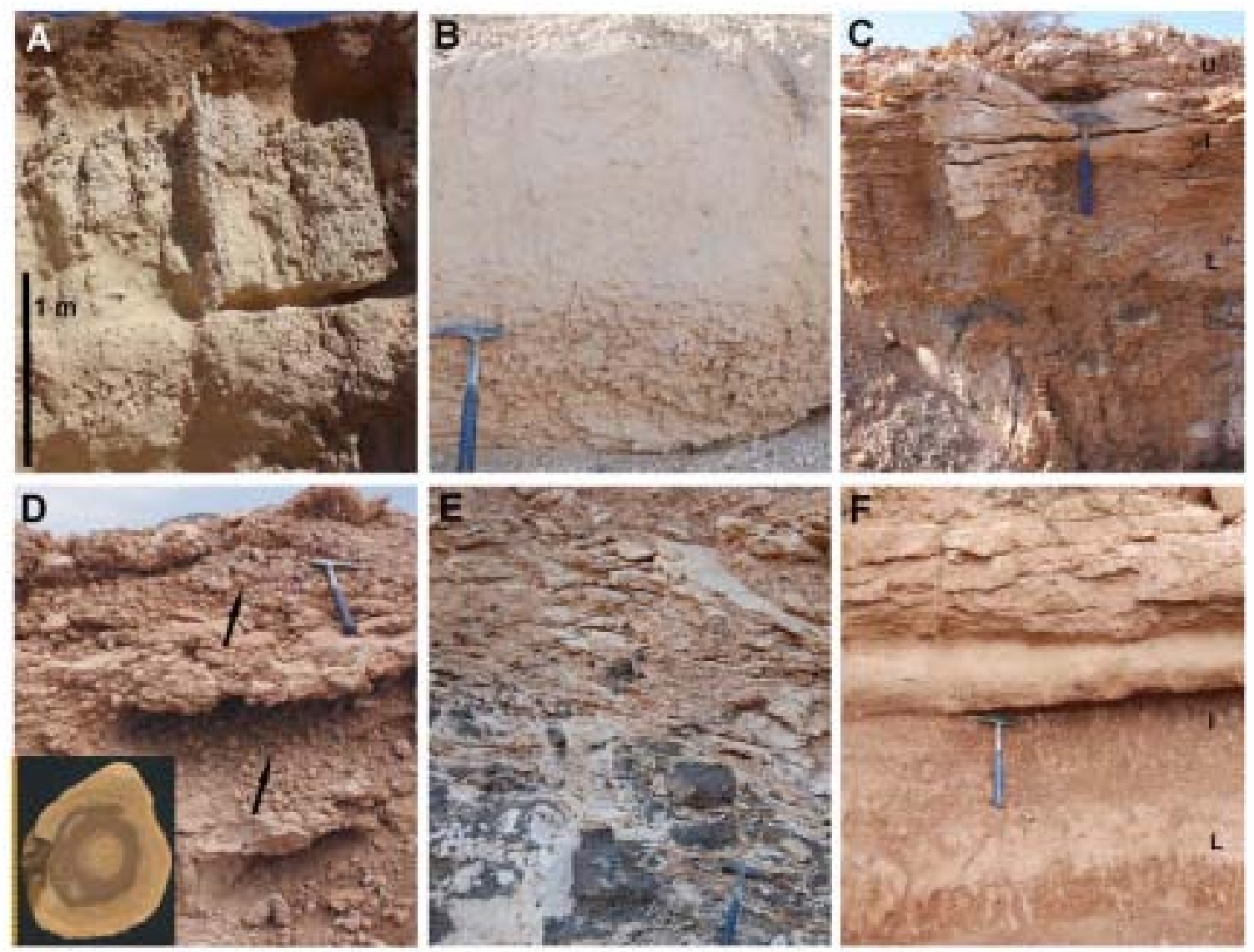

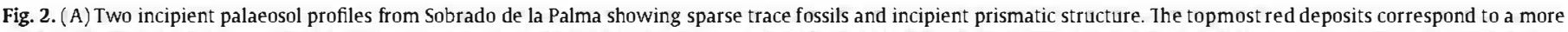

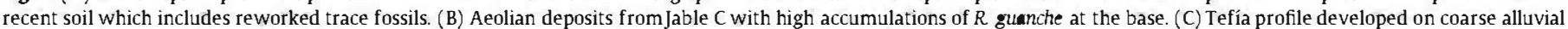

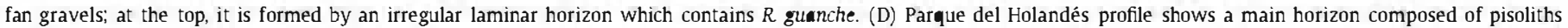

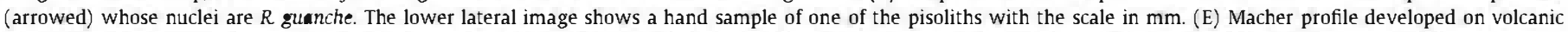

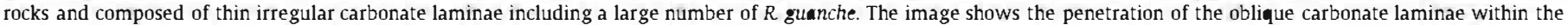
basalt. (F) Mirador del Río profile developed on red mudstones showing different relatively massive carbonate horizons.

\subsection{Petrology of the calcretes}

\subsubsection{Clay/micrite/volcanic glass mudstones with volcanic clasts}

The dark mudstones, in the Mirador del Rio profile, are composed of clays, micrite and an isotropic vitreous mass, and include large numbers of fragments of volcanic rock, 0.1-10 $\mathrm{mm}$ across. Micritic filaments are observed in the micrite matrix (Fig. 5A). Some grains display orange coatings of micrite + clay. The mudstones are traversed by a very irregular network of cracks that breaks the micrite and gives place to a crumbly texture. The cracks are either empty or filled with carbonate. Most are desiccation cracks that in some cases were enlarged by root activity, giving rise to irregular and wider cracks ( $2 \mathrm{~mm}$ ) filled by a mass of micritic filaments and needle-like calcite crystals.

\subsubsection{Desiccated sandy micrite}

It consists on a relatively homogeneous sandy micrite cut by irregular and commonly empty circumgranular desiccation cracks (Fig. SB). There are some sand-to-fine gravel-sized clasts, either of quartz, volcanic fragments, or rarely bioclasts. In some cases the number of cracks and crystal size in the micrite distinguishes the more homogeneous areas from other crumbly-like ones.

\subsubsection{Crumbly microfabrics}

The crumbly micrite has a well-developed network of commonly empty desiccation/root cracks. The number of cracks distinguishes micrite fragments of different sizes, the peloids $(<0.1 \mathrm{~mm})$, and the intraclasts (sand-to-gravel size; Fig. 5C). Some of these fragments show micritic coatings (ooids, see description below). The size of commonly found quartz grains, volcanic fragments, and some bioclasts ranges from $<0.1 \mathrm{~mm}$ to a few centimetres.

\subsubsection{Ooidal/peloidal microf abrics}

Very common ooidal/peloidal microfabrics within thick laminar horizons, as in Tefía profile, are composed of peloids (Fig. SD) and ooids (Fig. SE). The peloids are rounded and composed of homogeneous micrite, less than $0.1 \mathrm{~mm}$ in diameter. The ooids are also well-rounded carbonate grains, with a nucleus of micrite, quartz, volcanic, or carbonate rock and a number of micrite envelopes. The micrite envelopes are orange-brown in colour and in some cases show some birefringence, indicating the presence of clays. The ooid ranges in size from $0.08 \mathrm{~mm}$ to $4 \mathrm{~mm}$ across. The space between the peloids and ooids is either empty or occupied by micrite or microspar. Some micritic filaments were found in pore spaces and also within ooids.

\subsubsection{Laminar microf abrics}

They characterise both the laminar horizons and the pisolithic coating (Fig. 5F), such as those of Parque del Holandés profile. This microfabric consists of relatively dense micrite laminae with micritic filaments (Fig. 5G), alveolar septal structures and/or ooids (Fig. 5H). Some laminae also contain orange clays. The ooids are similar to the previously described ones. Some silt-sized calcite crystals and also quartz grains are included within the micrite. 


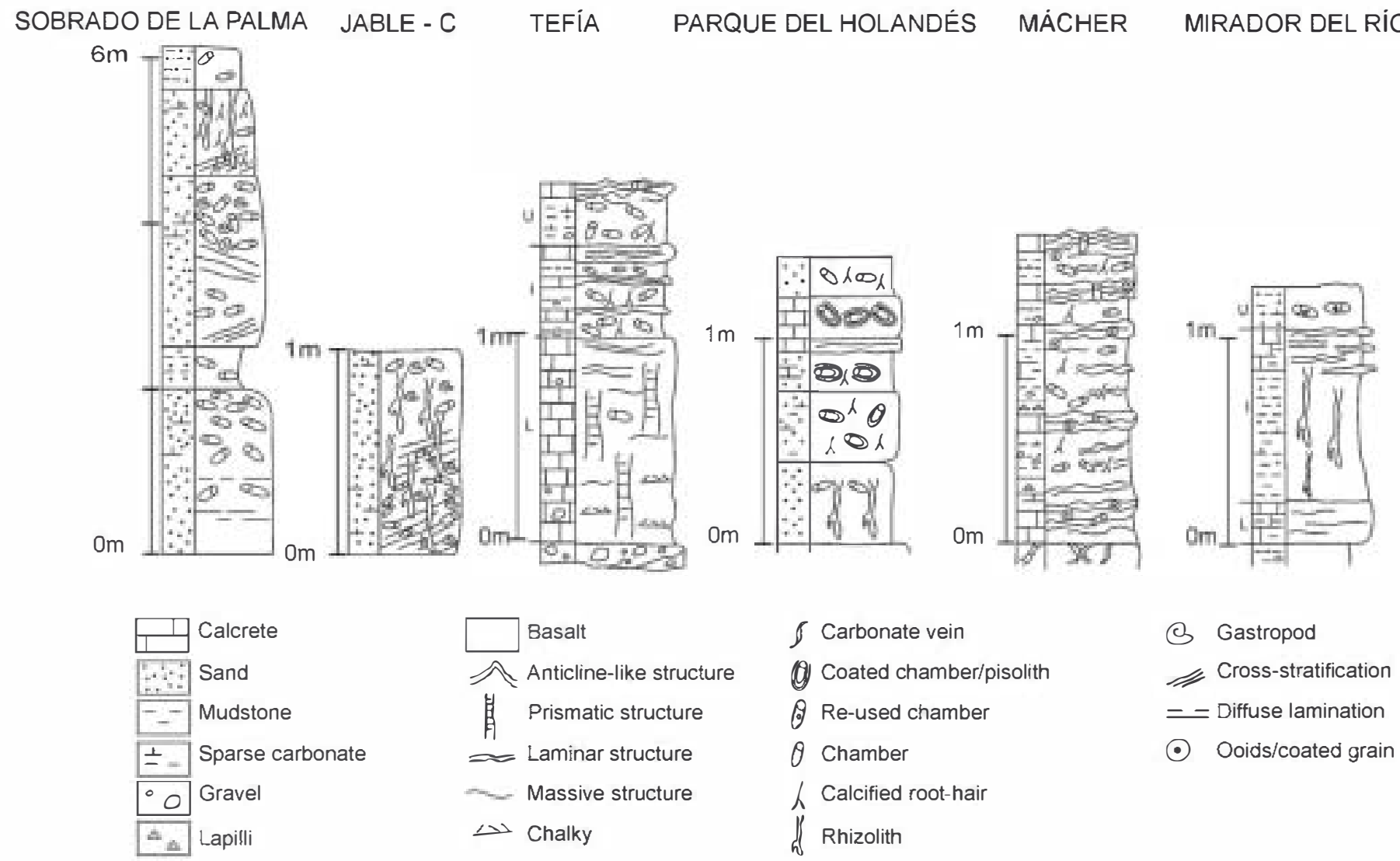

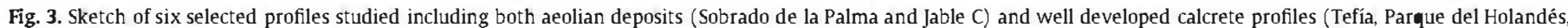
Mácher and Mirador del Río). The lower (L), intermediate (I) and upper (U) horizons described in the text for Tefía and Mirador del Río profiles are indicated.

\section{Systematic ichnology}

The trace fossils were deposited in the Colección de Fósiles del Museo de Ciencias Naturales de Tenerife (TFMCFO). Thin sections were deposited in the Litoteca del Departamento de Petrología y Geoquímica de la Facultad de Ciencias Geológicas de la Universidad Complutense de Madrid (L).

\subsection{Rebuffoichnus Roselli, 1987}

Diagnosis: Sub-ovoid to subcylindrical structures composed of a discrete wall, whose exterior aspect is rough and lumpy, whereas the interior is smooth or with a faint surface texture. The ellipsoid internal chamber has a circular cross-section. The wall may be perforated by a rounded hole (modified from Genise et al., 2002a). Type ichnospecies: Rebuffoichnus casamiquelai Roselli, 1987.

\subsubsection{Rebuffoichnus guanche isp. nov.}

2000. Type 2 cells Edwards and Meco p. 178 figs. 5d and 7d. 2003. Poorly-preserved specimens of Palmiraichnus Genise and Edwards p. 321 fig. 5.

Etymology: After the guanches, the aboriginal people of the Canarian Islands.

Holotype: A complete specimen (TFMCFO 6055), with emergence hole from Istmo de la Pared, Fuerteventura (Fig. 6A, B).

Paratypes: A complete specimen (TFMCFO 6056), with emergence hole, from the type locality; two broken specimens (TFMCFO 6072 and 6073; Fig. 6C, D), of longitudinal sections, from Mirador del Río, Lanzarote; and two broken specimens (TFMCFO 6076 and 6084; Fig. 6E, F), of longitudinal and cross sections, respectively, from Corralejo, Fuerteventura.
Diagnosis: Sub-cylindrical, flask-to-drop shaped structures composed of a discrete wall, whose exterior aspect may be rough and lumpy or more regular and sandy textured, whereas the interior is completely smooth or with a faintly grooved relief (Fig. 6G). The internal chamber is ellipsoid and circular in cross-section. At one end, there is a short, cylindrical-to-slightly conical antechamber. In closed specimens, the chamber and antechamber are separated by a partition that is convex and externally rough. Internally the partition is indistinguishable from the rest of the chamber wall. The partition may be preserved as a rim around the neck in specimens opened apically.

Remarks: This ichnospecies, having an antechamber, differs from the previously described ones of the ichnogenus, $R$. casamiquelai and $R$ sciuttoi. The presence of an antechamber makes these structures look like poorly preserved specimens of Palmiraichnus (Genise and Edwards, 2003). However, the new material observed and collected for this study shows that the partition between the chamber and the antechamber is not an operculum with an intemal spiral design as in Palmiraichnus, but a continuation of the internal smoothed lining following the outline of the ellipsoid chamber (Fig. 6C, D, F, H). The antechamber may be also confused with a second broken chamber of a series (Edwards and Meco, 2000). The clustering of two specimens is common (Genise and Edwards, 2003), particularly at Corralejo (this study; Fig. 6I), resulting in some cases in one bearing the bottom of other. However, the frequent recurrence of this pattern, interpreted as a chamber with an antechamber in hundreds of specimens and in all localities, in contrast with the scarcity of structures composed of two complete specimens in a series, leaves no doubt that this morphology is a distinct ichnospecies of Rebuffoichnus.

Description: The holotype (TFMCFO 6055) is a complete, dropshaped specimen (Fig. 6A, B). Its external surface is somewhat rough or bumpy, covered by a thin carbonate layer. The main chamber, circular in cross section, is connected to the antechamber by a neck with a 

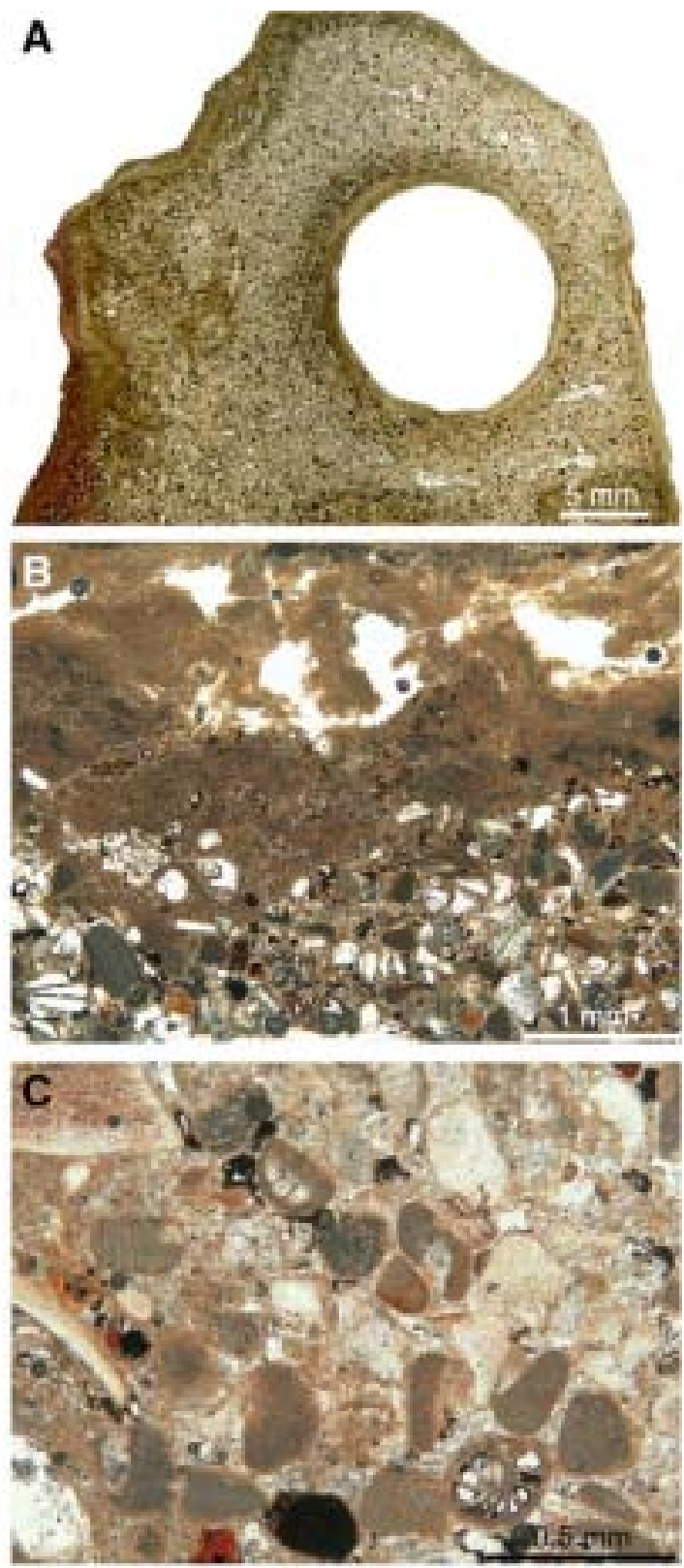

Fig. 4. Petrology of the aeolian deposits. (A) Thin section showing a central rounded pore corresponding to the central cavity of one chamber. The chamber wall consists of laminated micrite, similar to the one that coats the sand of the palaeosol. (B) Thin section showing an intercalation of porous micrite with alveolar structure, indicating root activity. (C) Most of the sand grains show thin brown micritic coating. In some cases the coatings of the different grains are joined by micritic bridges.

rim (Fig. 6B). The specimen is $36 \mathrm{~mm}$ long and $24 \mathrm{~mm}$ in maximum diameter. The internal chamber is $20 \mathrm{~mm}$ long. The aperture diameter is $10 \mathrm{~mm}$. The antechamber is $10 \mathrm{~mm}$ long, whereas its intemal and external diameters are $11 \mathrm{~mm}$ and $19 \mathrm{~mm}$, respectively. The paratype (TFMCFO 6056) is a complete specimen, showing a more pronounced drop shape than the holotype. It is $38 \mathrm{~mm}$ long and $24 \mathrm{~mm}$ in maximum diameter. The internal chamber is $20 \mathrm{~mm}$ long. The aperture diameter is $8 \mathrm{~mm}$. The antechamber is $10 \mathrm{~mm}$ long, whereas its intemal and extemal diameters are $11 \mathrm{~mm}$ and $19 \mathrm{~mm}$ respectively. Paratypes (TFMCFO 6072 and 6073; Fig. 6C, D), and (TFMCFO 6076) are weathered specimens with their longitudinal sections exposed. Their lengths range from $5 \mathrm{~cm}$ to $3.4 \mathrm{~cm}$ and their maximum diameters from $2.5 \mathrm{~cm}$ to $2 \mathrm{~cm}$. Chamber lengths range from $3.5 \mathrm{~cm}$ to $2.5 \mathrm{~cm}$. The remaining paratype (TFMCFO 6084; Fig. 6E) is broken in two pieces showing that the internal chamber has both extremes smoothed (Fig. 6F). Externally, remains of the antechamber can be seen. The specimen is $3.5 \mathrm{~cm}$ long and $2 \mathrm{~cm}$ in maximum diameter. The four latter paratypes, along with other examined specimens (Fig. $6 \mathrm{H}$ ), show that both extremes of the intemal chamber are similarly rounded and smooth, displaying no signs of a particular closure.

The size and measures of the 298 examined specimens are highly diverse. Lengths range from $18 \mathrm{~mm}$ to $56 \mathrm{~mm}$ and maximum diameters from $12 \mathrm{~mm}$ to $30 \mathrm{~mm}$. Lengths of the internal chamber range from $12 \mathrm{~mm}$ to $27 \mathrm{~mm}$ and diameters from $9 \mathrm{~mm}$ to $16 \mathrm{~mm}$. Antechambers are up to $14 \mathrm{~mm}$ long, with internal diameters ranging from $9 \mathrm{~mm}$ to $15 \mathrm{~mm}$ and external ones from $10 \mathrm{~mm}$ to $25 \mathrm{~mm}$. Wall thickness ranges from $2 \mathrm{~mm}$ to $8 \mathrm{~mm}$, which is probably related to the amount of carbonate precipitated. As noted by previous authors (i.e. Ellis and Ellis-Adams, 1993; Edwards and Meco, 2000; Genise and Edwards, 2003) walls range from thinner ones, sandy textured, showing little carbonate to the naked eye (Fig. 6M), to thicker ones, in which the original texture is completely obliterated by carbonate overgrowth (Fig. 6K, L). Extreme cases of carbonate coatings were considered pisoliths (Alonso-Zaiza et al., 2012). Specimens from Corralejo localities show two features of these trace fossils already described in the previous bibliography: cross-cuttings or clustering between specimens (Fig. 6I) and the extensive presence of Tombownichnus plenus and T. parabolicus in their walls (Mikuláš and Genise, 2003; Genise and Edwards, 2003; Fig. 6E). Percentages of Tombownichnus reach up to $59 \%$ in Corralejo, $65 \%$ in Corralejo C, and $71 \%$ in Corralejo B. Two thin sections show small cocoons inside specimens of $R$. guanche, suggesting the tempting idea that both cocoons and Tombownichnus were made by the same producer. At Corralejo $\mathrm{B}, 18 \%$ of the specimens show remains of other chambers attached (TFMCFO 6080), and in two cases (TFMCFO 6081) smaller specimens fit perfectly inside larger ones (Fig. 6M). Most specimens are oriented horizontally to sub-horizontally in the palaeosols (Figs. 2A, B; 9E, F). Some of the specimens show associated vertical burrows arising from the equator (Fig. 9C) or subhorizontal ones arising from one end (Fig. 9D).

Petrology: Some of the specimens show an inner and/or outer lining as a distinct character. Two types of linings were recognised: 1) thin $(30 \mu \mathrm{m})$ linings were recorded in a few races. They are micritic to clayey and discontinuously coat the inner surface of the wall chamber (Fig. 7A); in one case, the lining enters inside the cavity outlining an ovoid-like structure compatible with a small cocoon; and 2) thicker laminated micrite linings $(0.5 \mathrm{~mm})$, altemating between grey and darker laminae, in some cases coating the internal and extemal surfaces of the wall chamber (Figs. 7B, C). The lining can be slightly birefringent and redder, indicating the presence of oriented clays. Chamber walls consisting of sands with coated grains occur in aeolian deposits or in poorly developed calcretes. Perographically they are to the aeolian deposits. The walls, about $2.5 \mathrm{~mm}$ thick, have well-defined internal surfaces, whereas the extemal ones are more irregular. The sand grains are well sorted and the elongated grains are oriented parallel to the cavity (Fig. 7D). The oriented grains occur either throughout the wall $(2.5 \mathrm{~mm})$ or only in the innermost part $(1.2 \mathrm{~mm})$. In the infill of the cavity, the sands range from well-to-moderately sorted without preferential orientation. The wall is darker than the hostrock because the space among grains is occupied by micrite or microspar (Fig. 7E). Degree of packing and matrix abundance are lesser in the cavity than in the wall, and in the wall greater than in the hostrock (Fig. 7E). Sands are composed mostly of various types of bioclast fragments (echinoid, red algae, and molluscs), some quartz grains and minor fragments of volcanic rocks. Most of the grains are coated by a thin brown micritic envelope as described for the aeolian deposits.

Chamber walls consisting of ooidal/peloidal microfabric (Fig. 7F) are found mostly in well developed calcretes. The microfabric consists of two types of carbonate grains: ooids and peloids. The ooids range from $0.1 \mathrm{~mm}$ to $1 \mathrm{~mm}$ in diameter and consist of a nucleus wrapped 

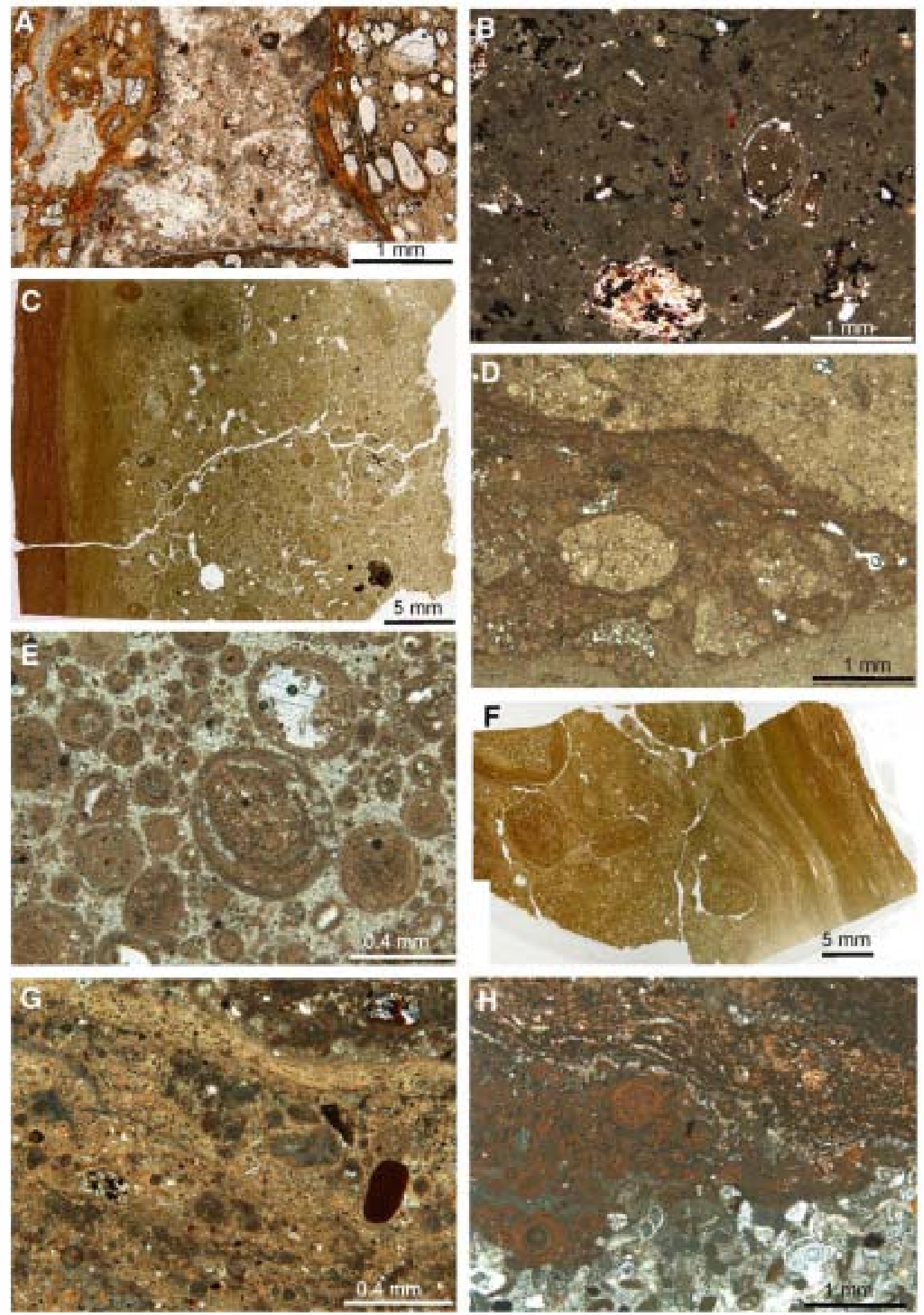

Fig. 5. Microfabric of the calcretes. (A) The matrix between the large volcanic fragments is composed by a mass of micritic filament. (B) Micrite with circum-granular desiccation cracks (curve planes). (C) Crumbly microfacies consisting of rounded to angular micritic fragments embedded in micrite. Top (left) is composed of laminated micrite grains. (D) Peloidal microfabric; peloids are small rounded micritic grains. (E) Ooidal microfabric, in which the ooids show different sizes and micritic coatings. The nuclei are either micritic or detrital grains. (F) Composed microfabric with pisoliths. At the top (right), the whole sample is overlain by laminated micrite. (G) Laminar microfabric showing some micritic filaments. (H) Iaminar microfabric formed by micrite and ooids.

by relatively regular micrite coatings, which may alternate with more clayey laminae. In some cases, clay shows birefringence. The nucleus may be a bioclast, quartz, a volcanic grain, or micrite. The peloids are smaller grains, commonly less than $0.2 \mathrm{~mm}$, and lack any coating.
Quartz, volcanic, and bioclast grains are also present in this microfabric as well as more angular and micrite carbonate fragments. Space between the grains is occupied by micrite, microspar, or may be empty. Some of the chambers are diffusely laminated due to the heterogeneous 

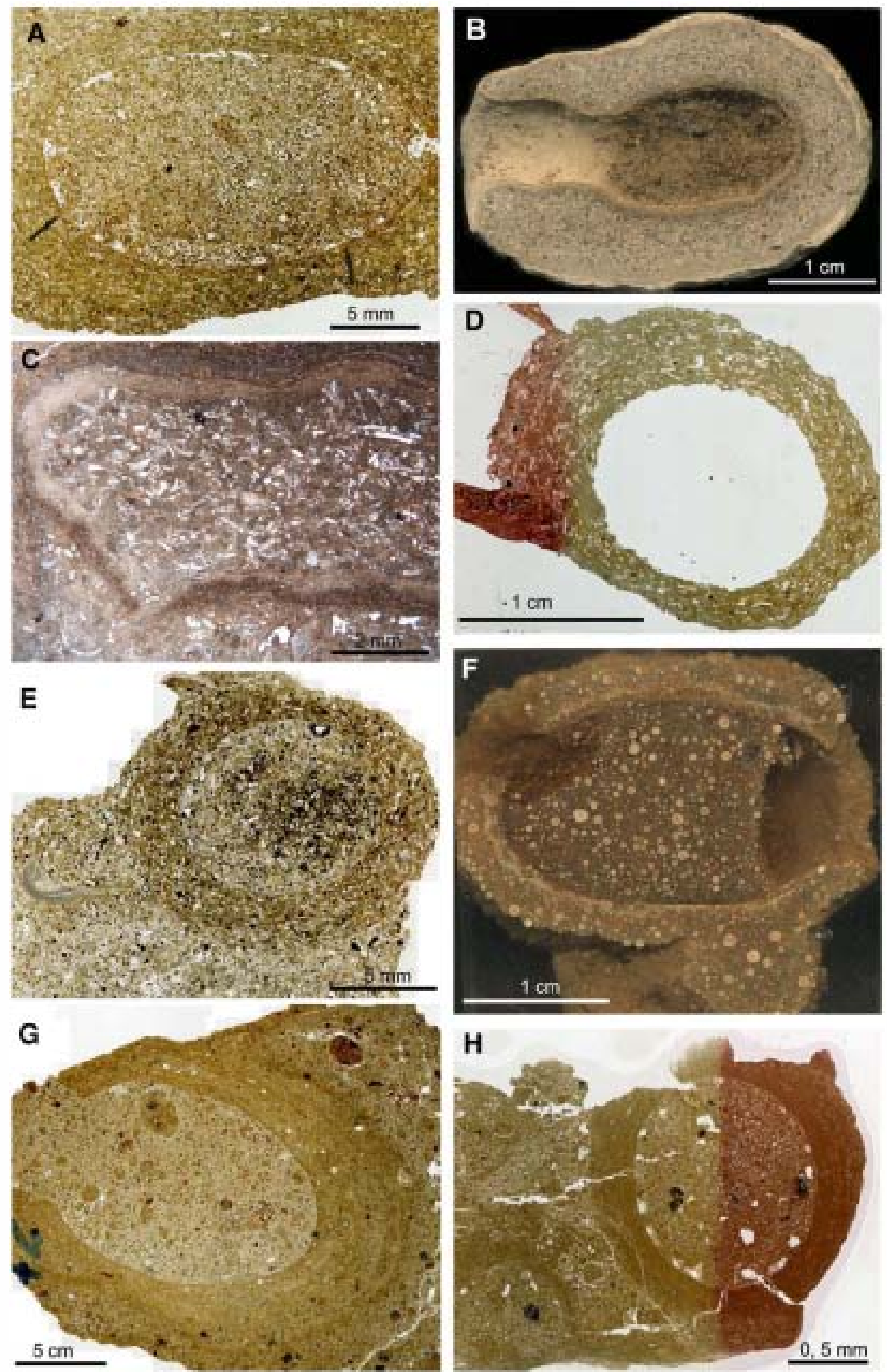

Fig. 7. Microf abric of $R$ guanche. (A) Iongitudinal section showing a thin coating in the inner surface of wall (black arrows). (B) Iongitudinal section showing the internal and external wall surfaces coated by white carbonate. (C) Thin section of B, showing the inner thicker coating, composed of micrite and clay. (D) Cross secrion showing the wall formed by sand grains embedded in micrite, the elongated grains are oriented parallel to the chamber walls. (E) Cross section showing the wall formed by sand grains with a darkening due to the high content of micrite matrix. The infilling material consists of sands with micrite matrix. (F) Longitudinal section showing the wall formed mostly by ooids embedded in micrite. The cavity is filled by larger ooids. $(\mathrm{G})$ and $(\mathrm{H})$ Cross sections showing the walls consisting of diffusely laminated micrite, whereas the hostrock is a more porous and non-laminated micrite. The infilling material is composed of sandy micrite. 

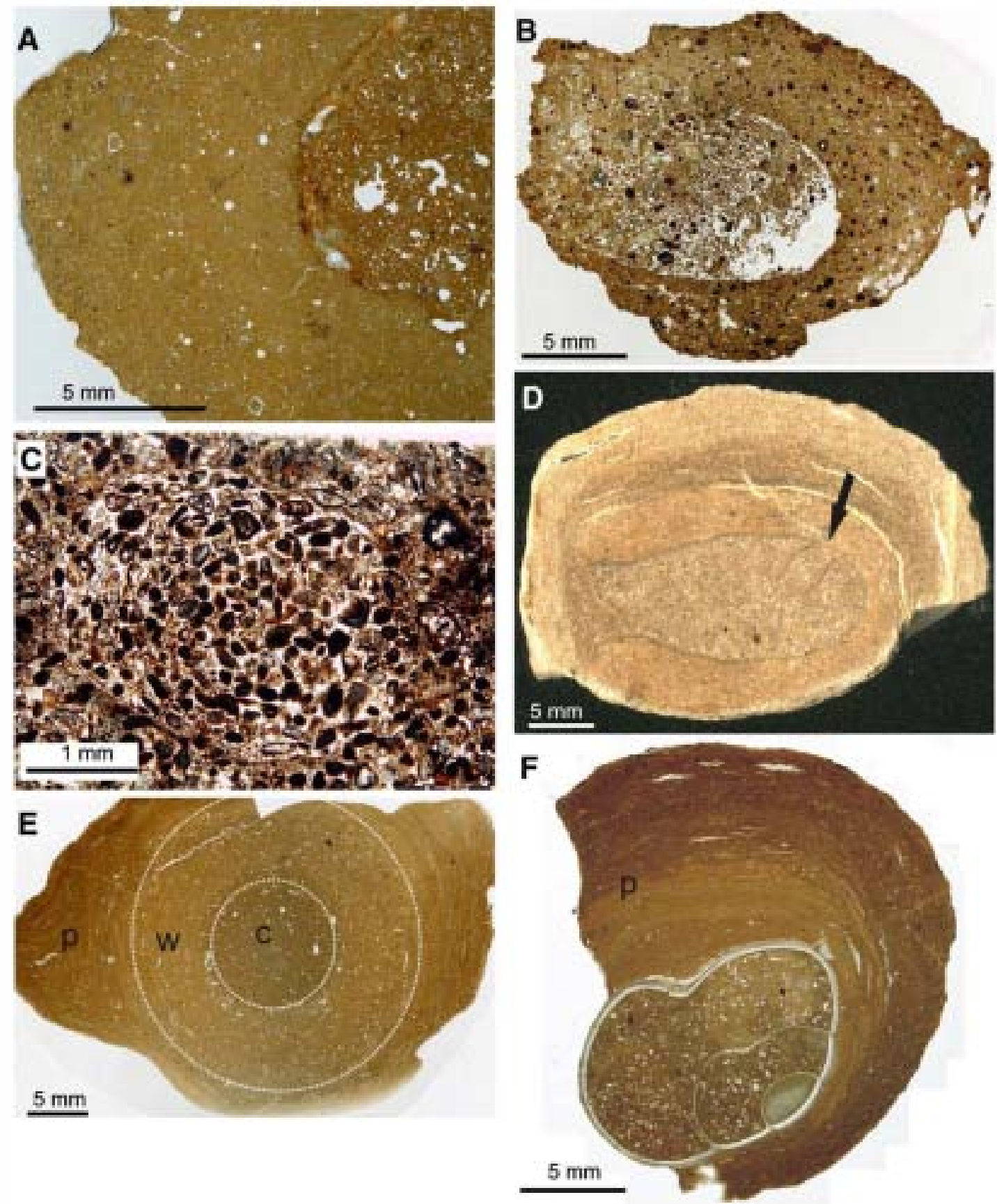

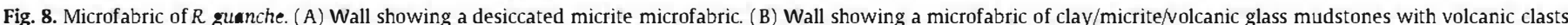

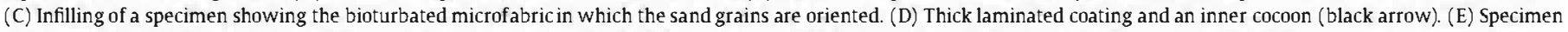
showing the inner cavity $(c)$, the wall $(w)$ and a thick laminated pisolithic ( $p$ ) coating. (F) Thick laminated pisolithic coating (p) on a gastropod shell.

et al., 2012), and thus the separation of the trace fossil itself from the coatings is difficult. Thick laminated micritic coatings are found not only on the traces but also on gastropods (Fig. 8F). In sum, microscopically Rebuffoichnus is very similar to the deposit in which they are found. Specimens found in aeolian deposits are composed by sand, whereas those found within the calcretes have more carbonate and its texture is compatible with that of the calcrete in which they are found.

\subsubsection{Rebuffoichnus casamiquelai Roselli, 1987}

1925 'Calcareous insect puparia' Lea p. 35

1987 Rebuffoichnus casamiquelai Roselli p. 24.

2002a Rebuffoichnus casamiquelai: Genise, Laza, Fernández and Frogoni p. 160. 2002b Rebuffoichnus casamiquelai: Genise, Sciutto, Laza, González and Bellosi p. 230.

2003 Rebuffoichnus casamiquelai: Genise and Edwards p. 322.

2004 Rebuffoichnus casamiquelai: Genise p. 432.

2007 Rebuffoichnus casamiquelai: Genise, Melchor, Bellosi, González and Krause p. 554.

2008 Rebuffoichnus casamiquelai: Sacchi and Petti p. 205

Comments: The type ichnospecies differs from $R$. guanche isp nov. in lacking an antechamber. This ichnospecies was previously cited for the Canarian Islands by Genise and Edwards (2003). For the present study, 41 collected specimens that lack antechamber, but that in all remaining characters and size resemble $R$. guanche, are formally included herein in $R$. casamiquelai. However, most 
probably these relatively few (12\%) specimens correspond to badly preserved specimens of $R$. guanche that lacked antechambers due to weathering.

\section{Discussion}

\subsection{Interpretation of aeolian deposits and calcrete profles}

The aeolian deposits of the Lanzarote and Fuerteventura Islands are mainly of two types: 1) Large sand blankets showing low-angle to horizontal stratification as those of Sobrado de la Palma or 2) Sands with high-angle cross bedding as in Jable $\mathrm{C}$, interpreted as large dune systems with well developed foresets. In both cases part of the sediments were modified by microbes, plants, and insect activity. The microbial activity was responsible for the formation of the constructive (Calvet and Juliá, 1983) and destructive micritic sand grain envelopes. Plants left their imprint in the formation of large vertical rhizoliths, as those found in Gran Canary Island (Alonso-Zarza et al., 2008), and/or palaeorhizospheres (Genise et al., 2011), which lack rhizoliths inside but preserve gastropods and trace fossils (Fig. 9A).

The microstructure of the various calcretes and their profiles was strongly influenced by host rock and degree of development of the calcretes. In the less developed calcretes such as in Mirador del Río the amount of carbonate is scarce and the clayey substrate shows a diversity of desiccation and/or root cracks. The presence of micritic filaments and needle fibre calcite strongly supports the role of microorganisms, particularly fungi, in their formation (Verrecchia et al., 2006; Bajnóczi and Kovács-Kis, 2006; Millière et al., 2011). The desiccated and crumbly microfabrics represent intermediate accumulations of carbonate and partial replacement of the substrate. Both microfabrics contain relicts of the substrate replaced by carbonate.
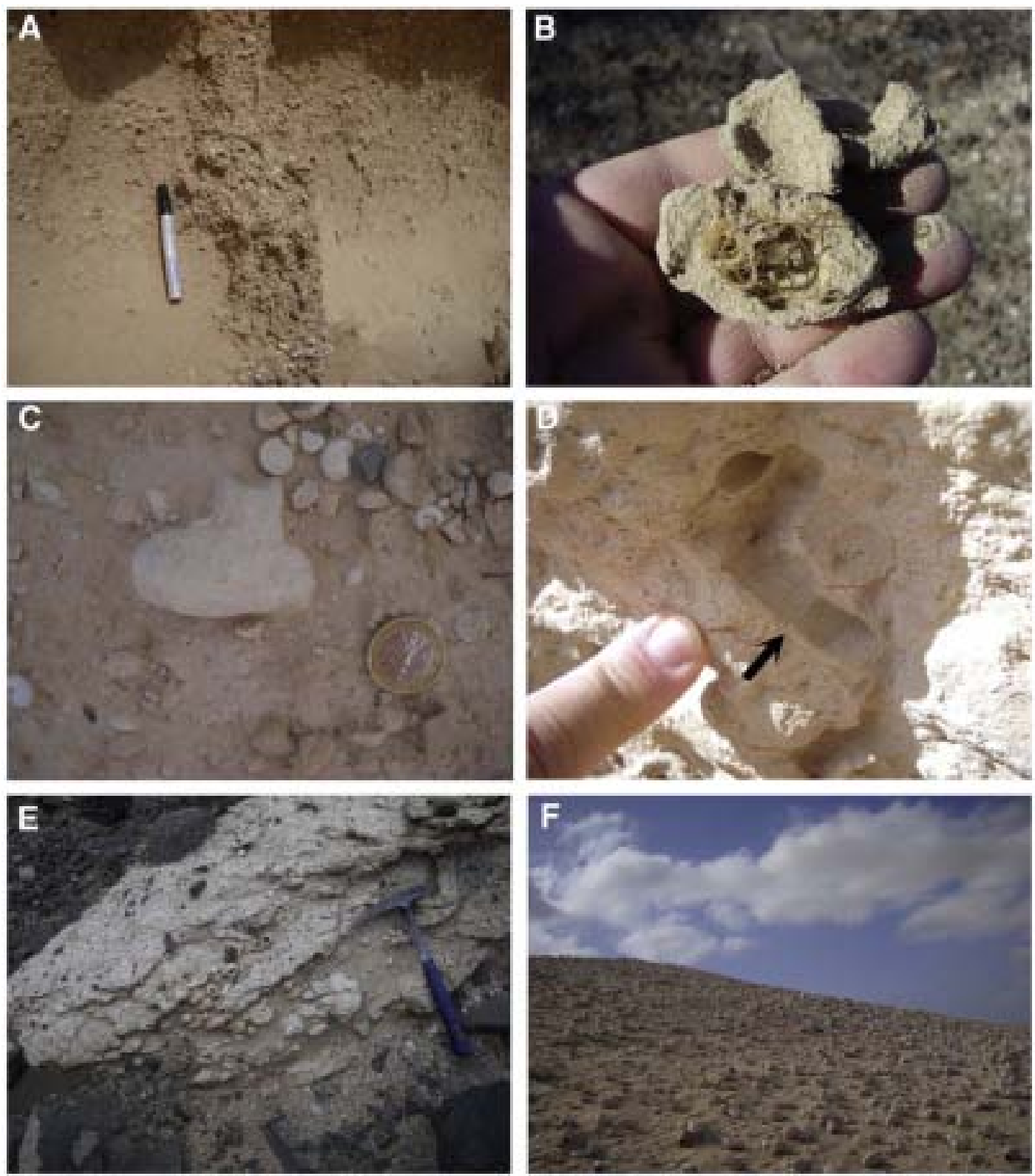

Fig. 9. (A) Palaeorizhosphere from Parque del Holandés including gastropods and Rebuffoichnusguanche. Pen: $15 \mathrm{~cm}$. (B) Root mats growing between the wall and the fillings of an extant coleopteran pupation chamber (Chubut, Argentina). (C) Specimen from Cañada Melián showing equatorial emergence tunnel. Specimen: $2.5 \mathrm{~cm}$ long. (D) Specimen from Cañada Melián showing apical and apparently elbowed emergence tunnel. Arrow shows connection between chamber (right) and tunnel (left). (E) Calcrete with a few specimens of $R$ guanche among basaltic rocks from Cofete. (F) Large accumulation of $R$. guanche in aeolian deposits of Corrale jo. 
The ooidal/peloidal and the laminar microfabrics reflect the maximum influence of roots and soil organisms on the formation of calcretes. Some peloids probably are faecal pellets, but others may be either micritic/clayey fragments, individualised and rounded within soil, or bacteria-induced precipitates (Zhou and Chafetz, 2009). Clays and detrital grains contained in the coating may be an indication that these grains rolled within the soil (Hay and Reeder, 1978; Hay and Wiggins, 1980). The penetration of root, root hairs and soil organisms, like insects, could aid in the movement of the ooids. During rolling the clays and detrital grains could have adhered to the surface of the nucleus and have become oriented tangentially, causing birefringence (Alonso-Zarza and Silva, 2002). Root, root hairs and soil organisms, like insects, could aid in the movement of the ooids. Laminar microfabrics indicate the maximum carbonate precipitation linked to the calcification of root-mats in which the metabolism of other organisms such as cyanobacteria (Vogt, 1984; Verrecchia et al., 1995) bacteria, fungi (Verrecchia and Verrecchia, 1994) or lichens (Klappa, 1980) could also induce carbonate precipitation. Physicochemical processes including the precipitation of micrite via increased carbonate concentrations in pond or capillary water, or through the formation of nonpedogenic structures such as vadose fibrous and coarse spar calcite cements (Alonso-Zarza and Wright, 2010), also contributed to the accumulation of carbonate in these profiles. Alonso-Zarza and Silva (2002) concluded that these, relatively thick, laminar calcretes were formed in a relatively stable landscape characterised by periods of low sedimentation rates.

The profiles are composite and formed by the addition of new sediment on the top of each of the calcrete carbonate laminae, as also described in the Ebro Basin (Meléndez et al., 2011). A different situation is found in Mirador del Río, where the thin calcrete is similar to incipient laminar calcretes as described in the Madrid and Duero Basin (Alonso-Zarza, 1999). In The Parque del Holandés profile the most striking feature is the presence of a whole pisolithic horizon in which the nuclei of most of the pisoliths are composed of Rebuffoichnus specimens coated with laminar fabrics similar to those of the laminar horizons (Alonso-Zarza et al., 2012). This reflects the probability that trace fossils favoured root mat location within soils, which associated with microorganisms contributed to the formation of the thick coating of the pisoliths. The presence of distinguishable root mats in the discontinuities between wall and soil, or wall and filling, is common in extant traces and trace fossils (Fig. 9B). In some specimens of Rebuffoichnus, emergence holes from the producers or parasites were occluded by this coating, clearly indicating that it was diagenetically deposited after chamber construction and emergence of occupants. Thick micritic envelopes have also been recognised on gastropod shells (Fig. 8F), indicating that they are not particularly related to trace fossil production but with later pedogenic/diagenetic processes. Independent of the degree of preservation of the substrate, the overall calcrete profiles of these islands indicate that root mats and soil microorganisms played a role in the formation of these profiles. According to previous studies, the calcrete profiles developed in the relatively wetter periods, of an arid to semi-arid climate, while the more arid periods were favourable to extensive aeolian or alluvial fan deposition (Danmati, 1997; Alonso-Zarza and Silva, 2002; Meco, 2008).

\subsection{Trace makers}

Since the earliest records of these Canary Island insect trace fossils, the attribution to bees, and particularly to anthophorids, was the rule (Bravo, 1954; Machado, 1976; Báez and Bacallado, 1984; Rothe, 1986; Petit-Maire et al., 1987; Ellis and Ellis-Adams, 1993; Edwards and Meco, 2000; Alonso-Zarza and Silva, 2002). These assignations were mostly based on the shape of structures, their resemblance to some thick walled cells built by anthophorids from the islands, and also because they were easily ascribed to the ichnogenus Celliforma, broadly defined to include all fossil bee cells (Brown, 1934), although recently restricted (Genise, 2000). Another argument also cited to attribute these trace fossils to bees was the presence of supposed allochthonous soil material within their walls (Edwards and Meco, 2000), typical of some hymenopterans. However, as explained by Genise and Edwards (2003) there is no known extant soil-nesting bee with that behaviour, restricted to hymenopterans constructing nests above surface on exposed substrates. Microfabric of wall and surrounding palaeosol documented for this study shows no differences in the material of wall chambers and those of the surrounding palaeosol in each locality studied.

Micromorphological characters detected, which can be attributed to the activities of insects, are: 1) thin micrite linings and darkening of walls (Figs. 7A, E), which are probably originated in organic excretions released by the insects during chamber construction (Genise et al., 2007), 2) orientation of elongated grains parallel to the cavity (Genise and Poiré, 2000) (Fig. 7D), and 3) incipient lamination of wall (Fig. 7G, H), which may be produced by pelletal construction (Genise and Hazeldine, 1998) or by discontinuous release of organic excretions (Farina et al., 2010).

Despite the previous consensus on bee origin for these trace fossils, Genise and Edwards (2003), analysing the structure of trace fossils in detail, pointed out that in all specimens documented by previous authors, or in their own study, no spiral closure was found, a common character of many fossil bee cells. Based on this and other characters, these authors proposed beetles or moths as other putative producers. The lack of spiral closure is also recorded herein for these trace fossils, further weakening the bee hypothesis. In contrast, other types of trace fossils represented by the ichnogenus Palmiraichnus (La Roche et al., 2010) found in Fuerteventura could be clearly attributed to fossil bee cells. Recently, Meco et al. $(2010,2011)$ proposed that locusts were the producers of the structures, named herein as Rebuffoichnus guanche. In their first contribution, Meco et al. (2010, p. 318) briefly mentioned that such a structure "occurs in billions... which evokes a "plague" of organisms" as a single argument to attribute them to "Acridian brood-nests" and to extract a lot of palaeoclimatic inferences related to historical locust swarms. Additionally, they mentioned that the size and morphology of the structures corresponded to protective devices of Acridian ootheca, documenting this with an old drawing (D'Ancona, 1959, in Meco et al., 2010). In a second contribution, Meco et al. (2011) repeated these arguments adding a picture of extant locust egg pods for comparison, whose elongated shapes and open ends contrast clearly with the ellipsoid shape and in some cases, both extremes closed, of the Canary Island trace fossils illustrated in the same contribution (Meco et al., 2011, figs. 2 and 7) and herein. Similarly, the mostly horizontal to sub-horizontal orientation of chambers shown in those figures, and documented herein, contrasts with the vertical to subvertical orientation of locust egg pods (Meco et al., 2010, fig. 5). In addition, emergence tunnels arising from the equator of $R$. guanche (Fig. 9C) or those sub-horizontally oriented (Fig. 9D) are not compatible with the locust pod hypothesis. This attribution to locusts is poorly supported, based on the large number of specimens recorded in each palaeosol, although it is impossible to ascertain if all specimens were produced at the same time by a single cohort of insects that represent a census population (i.e. locust swarms). Palaeosols correspond with periods of no erosion/no sedimentation that may represent a relatively long interval of time for the living soil (Retallack, 2001), in comparison with the annual or pluriannual reproductive cycle of insects producing the most common trace fossils. Accordingly, a single palaeosol may accumulate a huge number of trace fossils produced by different generations of insects, even of species of more or less solitary habits, such as bees or dung beetles (i.e. Sánchez et al., 2010). Discarding then the plague hypotheses, other hypotheses are equally poorly supported. The size and ellipsoid shape of Canary Island race fossils, with subtle differences, are very common and little diagnostic for distinguishing among producers of insect trace fossils in palaeosols (Genise, 2000, 2004). As documented in previous 
contributions, trace fossils with this similar shape can be attributed to different ichnogenera (Cellifornna, Palmiraichnus, Rebuffoichnus) and producers (bees, coleopterans, moths) (Ellis and Ellis-Adams, 1993; Edwards and Meco, 2000; Genise and Edwards, 2003). Accordingly, the identification of insect producers usually is never restricted only to size or shape of trace fossils, but to other detailed characters of their structure, such as surface texture, wall, etc. (Genise, 2004). In any case, the great dispersion of sizes is probably related to different sizes of producers, compatible with coleopterans of different species constructing the chambers, in contrast with a single species of migratory locust. Locust egg pods, as Meco et al. $(2010,2011)$ claimed, have always one open end, from where the female lays the eggs, and which is then closed with a foamy substance. The closed specimens of Rebuffoichnus illustrated herein (Fig. 6F, H) contradict the locust hypothesis. Furthermore, the smooth interior lining and concave shape of both ends are clearly indicative of a chamber constructed and smoothed completely from inside, as usual in coleopteran pupation chambers. No organism, not even a locust with its abdomen, can completely smooth the interior wall of a chamber from outside. The presence of antechambers in $R$. guanche with closed internal chambers demonstrates that antechambers were constructed before the chamber lining was completed, and accordingly, that antechambers are not produced by adult emergence.

The assignation of Rebuffoichnus to Curculionidae and Scarabaeidae (Coleoptera) was extensively discussed by Johnston et al. (1996) under the name of Fictovichnus, and by Genise et al. (2002b), who provided comparisons with extant coleopteran pupation chambers. Particularly, in support of this hypothesis, was the record of an adult weevil illustrated by Lea (1925, plate I) in a specimen of Rebuffoichnus casamiquelai from the Quaternary limestones of Australia. Ellis and Ellis-Adams (1993) discarded weevils as shown by Lea (1925) as producers of these Canary Islands race fossils because of the subapical location of the emergence hole. However, this location is equally apical or subapical in the Canary Islands outcrops (Fig. 6J), or in hundreds of specimens of Rebuffoichnus casamiquelai from elsewhere (Genise et al., 2002b). Counts and Hasiotis (2009, fig. 4) illustrated pupation chambers of one species of Scarabaeidae, which show ellipsoid shape and thick discrete walls similar to Rebuffoichnus.

The entomofauna of Canary Islands is diverse, with endemic genera and species of Curculionidae and also a certain number of species ofScarabaeidae (Oromi et al., 2004), which according to their size and habits, may qualify as potential producers of $R$. guanche. The adults of some of these species emerge in large numbers from soil, where they pupate, when climatic conditions are appropriate (I. Melendez, pers. comm., 2010). These massive emergences would leave a large number of pupation chambers, whose accumulation over years would result in comparable densities to those observed in palaeosols.

\subsection{Palaeonvironmental approach}

The levels with $R$. guanche were found in both calcretes and aeolian deposits. In the former, they are located in small to moderate numbers in relatively thin layers between laminar calcretes or included therein (Fig. 9E). These are considered as Canarian examples of the Cellifornna ichnofacies (Genise et al., 2010). The levels with $R$. guanche were commonly inserted between different calcrete laminae. One possibility is that larvae excavate down to the calcrete constructing the chambers on top, as it was too hard for larva to burrow in. Another possibility is that a high moisture horizon could trigger both root growth, forming laminar calcretes, and coleopteran pupation. Laminar calcretes overlaying $R$. guanche levels would have been consolidated after their construction and adult emergence, representing new episodes of sedimentation followed by soil/calcrete formation providing new sites for chamber construction. This explains the presence of the chambers in different levels within the calcretes. This palaeoenvironment suggests low to moderate numbers of coleopterans colonising and inhabiting incipient, relatively thin, former soils developed immediately over basaltic or sedimentary rocks. Thickness of wall chambers varies notably among localities and within the same locality/profile. Thinnest chambers are found in the aeolian deposits and their incipient calcretes, whereas the thicker are found in well developed calcretes, indicating that the thickness is linked to calcrete development and carbonate precipitation.

In contrast, in some aeolian deposits, such as Corralejo (Fig. 9F) and Jable, $R$. guanche constitute thick layers with an extremely large number of specimens, in some cases separated by other horizons lacking them. In addition, at Corralejo there is a high percentage of parasitism, evinced by the presence of Tombownichnus, and crosscuttings among trace fossils are frequent, suggesting more activity of the producers as well as of their associated entomofauna. The arrangement and amount of $R$. guanche within the aeolian deposits was probably influenced by different factors, including sedimentation rate and climate. The larger concentrations of $R$. guanche probably resulted from a combination of more prolonged periods without sedimentation, but with soil formation, during periods of rainfall increase, and intense chamber construction in a thin soil horizon with the precise micro-environmental conditions required by insects.

Aeolian deposits of these islands, having developed mostly in more arid periods, were capped by incipient development of soils/calcretes with increased insect activity (whatever the producer), presence of roots and insect traces, indicative of periods of increased rainfall as suggested previously (Edwards and Meco, 2000; Alonso-Zarza and Silva, 2002; Genise and Edwards, 2003; Meco, 2008). Differences in numbers of insect trace fossils in both palaeoenvironments suggest two possibilities: a) producers of $R$ guanche first colonised soils developed over the original basalts or sedimentary rocks maintaining populations oflow to moderate numbers up to the appearance of dunes, where they found plenty of substrate and more suitable conditions for living and pupating, or b) producers were typical inhabitants of dune environments, first colonising islands with aeolian environments and later colonising, to some extent, marginal soils with calcretes in hillsides to reduce competition. Geological evolution recorded for Canary Islands shows that the younger western Islands dominated by volcanic processes are more humid due to the wet winds coming from the west, whereas the eastern, older Islands such as Lanzarote and Fuerteventura are dominated by erosive, sedimentary, and soil formation processes leading to the formation of aeolian deposits and calcretes. Trace fossils are rare in Tenerife and are rarely found in La Palma, La Gomera, and El Hierro. In El Hierro, several specimens have been recognised within red clastic deposits overlain by a laminar calcrete, near Valverde by one of us (AMAZ). The presence of smaller numbers of trace fossils in the calcretes of the westem, younger, islands, devoid of aeolian deposits, suggests that the evolutionary path (a) is the most probable.

\section{Conclusions}

1) The most common and widespread insect trace fossils from Canary Islands, atributed to the ichnogenera Celliforma, Palmiraichnus or Rebuffoichnus, in previous contributions, are included herein in a new single ichnospecies of the latter ichnogenus: Rebuffoichnus guanche isp. nov.

2) Unlike the usual atribution to bees, and a more recent one, to locusts, $R$ guanche are considered herein as coleopteran (Curculionidae or Scarabaeidae) pupation chambers. The lack of spiral closure contradicts a bee origin. The mostly horizontal orientation in soils, ellipsoid shape, and particularly the interior wall of the chamber completely smoothed from its inside, support the coleopteran hypothesis. This origin is also supported by the record of one adult weevil in a similar race fossil and palaeoenvironment of Australia. These characters, and the dispersion of sizes, also argue against their assignation to egg pods of a locust species.

3) The wall of $R$ guanche shows a diversity of features that are very similar to those of the palaeosol in which specimens are found. 
Those specimens found in aeolian deposits are composed of sand grains similar to those found in the dunes or sand sheets. The diversity of microfabrics found in calcretes is higher and depends on the calcrete hostrock and the degree of development of the calcretes. In poorly developed calcretes the trace fossils reflect very well the calcrete hostrock, whereas in more developed ones they usually show peloidal/ooidal or laminar microfabrics. The similarities between the substrate (sediment/calcrete) microfabrics and those found in the trace fossils indicate that, in contrast to previous reports, insects utilised as building material that of the surrounding soil as attested by pupation chambers of extant Scarabaeidae.

4) Lower numbers of $R$. guanche are recorded in calcretes from the western Canary Islands, where no aeolian deposits are present, in contrast to the high densities in the aeolian deposits of the eastem Islands. Coleopterans would first colonise thin soils with calcretes developed on basaltic or sedimentary rocks in young islands and later colonise dunes as they appear when the islands aged. Dunes would provide plenty of living and pupating space in periods of increased rainfall and soil formation, leading to the highest densities recorded.

5) Calcrete features are indicative of the important role of roots and associated microorganisms in calcrete formation. Both the calcretes and trace fossils formed during the relatively wetter periods within otherwise prevailing arid to semiarid conditions. These periods of greater humidity favoured the installation of sparse vegetation cover either on the basalts, sand dunes or clastic deposits, leading to calcrete formation.

6) The widespread presence of calcretes, aeolian deposits and race fossils in the easternmost and older Canary Islands is driven by both climatic conditions and the geological evolution of the Islands.

\section{Acknowledgements}

We thank Jose Mangas for information on trace fossil localities and two anonymous reviewers and the Editor Finn Surlyk for improving the manuscript. This research was funded by Projects CGL-200805584-C02-02 and CGL-2011-27826-C02-01 from the MCINN to Ana M. Alonso-Zarza, FONCYГ PICГ 1972 from the Agencia Nacional de Promoción Científica y Tecnológica of Argentina to Jorge F. Genise, and FCE 2007/44 of the Agencia Nacional de Investigaciones del Uruguay to Mariano Verde. J. Cerne carefully reviewed the text style.

\section{Appendix I. Examined material}

\section{Rebuffoichnus guanche isp. nov.}

292 specimens from Lanzarote and Fuerteventura, most of them grouped in lots, as follows: Punta Papagayo (3) (TFMCFO 6061), Macher (1) (TFMCFO 6054), Mirador del Río (10) (TFMCFO 6074), Ye (21) (TFMCFO 6043), Tao (3) (TFMCFO 6062), San Bartolomé B (12) (TFMCFO 6071), Teguise (9) (TFMCFO 6050-1), Jable A (5) (TFMCFO 6059), Jable B (9) (TFMCFO 6064), Jable C (22) (TFMCFO 6063), from Lanzarote. Tefía (5) (TFMCFO 6046), Ampuyenta (6) (TFMCFO 6069), Tiscamanita (5) (TFMCFO 6067), Cementerio de Jandía (6) ( IFMCFO 6044), Parque del Holandés (14) (TFMCFO 6049), Istmo de la Pared (11) (TFMCFO 6057), Corralejo A (39) (TFMCFO 6085), Corralejo B (71) (TFMCFO 6080-82), Corralejo C (34) (TFMCFO 6075, 6077 and 6078), and Jable de Jandía (6) (TFMCFO 6065), from Fuerteventura. Examined thin sections were: Ianzarote: Playa Blanca (L 110.794), San Bartolomé (L359 110.756-110.759), Macher A (L 110.760), Macher B (L 110.762,110.763, 110.768, 110.770-110.772), Mirador del Río (L 110.774-110.775), Yé (L 110.777,110.779, 110.781, 110.782), Tao (L 110.790), Teguise (L 110.784), and Jable (L 110. 785-110.787, 110.789). Fuerteventura: Tefía (L 110.816), Ampuyenta (L 110.808, 110.810), Casas de Pecenescal (L 110.833-110.834), Cementerio de Jandía (L 110.820-110.821), Parque del Holandés B (L 111.419-111.416), Cofete
(L 111.424-111.427), Istmo de la Pared (L 110.825-110.828), Cañada Melián (L 111.418, 111.420, 111.421), and Corralejo (L 110.811, $110.812,110.829-110.831)$.

\section{Rebuffoichnus casamiquelai}

41 specimens from Lanzarote and Fuerteventura some of them grouped in lots as follows: Ye (9) (TFMCFO 6036-42), Teguise (1) ( TFMCFO 6052), Macher (1) (TFMCFO 6053), Jable A (TFMCFO 6058), Punta Papagayo (1) (TFMCFO 6060), and San Bartolomé B (1) (TFMCFO 6070) from Lanzarote. Tefía (2) (TFMCFO 6045), Ampuyenta (2) ( TFMCFO 6068), Parque El Holandés (7) (TFMCFO 6047-48), Jable de Jandía (5) (TFMCFO 6066), Corralejo B (2) (TFMCFO 6079), and Corralejo A (8) (TFMCFO 6083) from Fuerteventura.

\section{References}

Alonso-Zarza, A.M., 1999. Initial stages of laminar calcrete formation by roots: examples from the Neogene of central Spain. Sedimentary Geology 126, 177-191.

Alonso-Zarza, A.M., Silva, P.G., 2002. Quaternary laminar calcretes with bee nests: evidence of small-scale climatic fluctuations, Eastern Canary Islands, Spain Palaeogeography, Palaeoclimatology, Palaeoecology 178, 119-135.

Alonso-Zarza, A.M., Wright, V.P., 2010. Calcretes. In: Alonso-Zarza, A.M., Tanner, L.H. (Eds.), Carbonates in Continental Settings: Processes, Facies and Applications. : Developments in Sedimentology, 61. Elsevier, Amsterdam, pp. 226-268.

Alonso-Zarza, A.M., Genise, J.F., Cabrera, M.C., Mangas, J., Martín-Pérez, A Valdeolmillos, A, Dorado-Valiño, M., 2008. Megarhizoliths in Pleistocene aeolian deposits on Gran Canaria (Spain): ichnological and palaeoenvironmental significance. Palaeogeography, Palaeoclimatology, Palaeoecology 265, 39-61.

Alonso-Zarza, AM., Genise, J.F., Verde, M., Meléndez, A, 2012. Calcrete and insect trace micromorphology from the Pleistocene paleosol profiles of the Canary Islands. 14th International Working Meeting on Soil Micromorphology, Lleida, Spain.

Ancochea, E., Barrera, J.L., Bellido, F., Benito, R., Brăndle, J.L., Cebriá, J.M., Coello, J., Cubas, C.R., De La Nuez, J., Doblas, M., Gómez, J.A, Hernán, F., Herrera, R., Huertas, J.M., López Ruiz, J., Martí, J., Muñoz, M., Sagredo, J., 2004. Canarias y el Vulcanismo Neógeno penínsular. In: Vera, J.A. (Ed.), Geología de España. SGEIGME, Madrid, pp. 635-682.

Aranda Millán, F., 1909. Sobre Moluscos de Lanzarote (Canarias). Boletín de la Real Sociedad Española de Historia Natural 9, 112-114

Báez, M., Bacallado, J.J., 1984. Ios fósiles de Canarias. In: Bacallado, J.J. (Ed.), Fauna (marina y terrestre) del Archipiélago Canario. Edirca, Ias Palmas de Gran Canaria, pp. 343-347.

Bajnóczi, B., Kovács-Kis, V., 2006. Origin of pedogenic needle-fiber calcite revealed by micromorphology and stable isotope composition-a case study of a Quaternary paleosol from Hungary. Chemie der Erde 66, 203-212.

Bravo, T., 1954. Geografía General de las Islas Canarias 1. Editorial Goya, Tenerife $1-410$

Brown, R.W., 1934. Celif forma spirifer, the fossillarval chambers of mining bees. Journal of the Washington Academy of Sciences 24, 532-539.

Calvet, F., Juliá, R., 1983. Pisoids in the caliche profiles of Tarragona (NE Spain). In: Peryt, T.M. (Ed.), Coated Grains. Springer, Berlin, pp. 73-79.

Carracedo, J.C., Day, S., Guillou, H., Rodriguez Badiola, E., Cañas, J.A., Pérez Torrado, F.J 1998. Hotspot volcanism close to a passive continental margin; the Canary Islands. Geological Magazine 135, 591-604.

Carracedo,J.C., Pérez Torrado, F.J., Ancochea, E., Meco,J., Hernán, F., Cubas, C.R., Casillas, R., Rodríguez-Badiola, E., Ahijado, A., 2002. Cenozoic volcanism 11: the Canary Islands. In: Gibbons, W., Moreno, T. (Eds.), The Geology of Spain. Geological Society of London, pp. 439-472.

Carracedo, J.C., Pérez Torrado, F.J., Rodríguez Badiola, E., 2008. Canarias: Islas volcánicas intraplaca. In: Pérez Torrado, F.J., Cabrera, M.E. (Eds.), Itinerarios geológicos por las Islas Canarias, Gran Canaria: Sociedad Geológica de España, Geo-Guías, 5, pp. $11-25$

Counts, J.W., Hasiotis, S.T., 2009. Neoichnological experiments with masked chafer beetles (Coleoptera: Scarabaeidae): implications for backfilled continental trace fossils. Palaios 24, 74-91.

Criado, C, 1988. Evolución Geomorfológica de Fuerteventura. Ph.D. Universidad de La Laguna, Tenerife. $971 \mathrm{pp}$.

D'Ancona, H., 1959. Trattato di Zoologia. Unione Tipografico-Editrice Torinese, Torino.

Danmati, B., 1997. Mineralogical and sedimentological characterization of Quaternary eolian formations and paleosols in Fuerteventura and Lanzarote (Canary Island, Spain). In: Meco, J., Petit-Maire, N. (Eds.), Climates of the Past. Servicio de Publicaciones Universidad de Ias Palmas de Gran Canaria, pp. 71-77.

Edwards, N., Meco, J., 2000. Morphology and palaeoenvironment of the brood cells of Quaternary ground-nesting solitary bees (Hymenoptera, Apidae) from Fuerteventura, Canary Islands, Spain. Proceedings of the Geologists' Association 111, 173-183.

Ellis, W.E., Ellis-Adam, A.C, 1993. Fossil brood cells of solitary bees from Fuerteventura and Lanzarote, Canary Islands (Hymenoptera: Apoidea). Entomologische Berichten 53, 161-173.

Farina, J.L., Verde, M., Genise, J.F., 2010. The constructor of Teisseirei Roselli, 1939. Libro de Resúmenes del Simposio Iatinoamericano de Icnología. UNISINOS, Sao Lepoldo, Brasil, p. 33. 
Füster, J.M., Cendrero, A. Gastesi, P., Ibarrola, E., Iópez Ruiz, C., 1968a. Geología y Volcanología de las Islas Canarias. Fuerteventura.Inst. Lucas Mallada (CSIC), Madrid

Füster, J.M., Fernández Santín, S., Sagredo, J., 1968b. Geología y volcanología de las Islas Canarias: Ianzarote.Instituto Lucas Mallada (CSIC), Madrid.

Genise, J.F., 2000. The ichnof amily Celliformidae for Celliform and allied ichnogenera. Ichnos 7, 267-284.

Genise, J.F., 2004. Ichnotaxonomy and ichnostratigraphy of chambered trace fossils in palaeosols attributed to coleopterans, termites and ants. In: Mcllroy, D. (Ed.), The Application of Ichnology to Palaeoenvironmental and Stratigraphic Analysis: Special Publications of the Geological Society of London, 228, pp. 419-453.

Genise, J.F., Edwards, N., 2003. Ichnotaxonomy, origin, and paleoenvironment of Qwaternary insect cells from Fuerteventura, Canary Islands, Spain. Journal of the Kansas Entomological Society 76, 320-327.

Genise, J.F., Hazeldine, P.L. 1998. The ichnogenus Palmiraichnus Roselli for fossil bee cells. Ichnos 6, 151-166.

Genise, J.F., Poiré, D.G, 2000. Fluidization in insect constructions in soils. Ichnos 7, 127-134

Genise, J.F., Laza, J.H., Fernández, W., Frogoni, J., 2002a. Cámaras pupales fósiles 893 s de coleópteros: el icnogénero Rebuffoichnus Roselli. Revista del Museo Argentino de Ciencias Naturales 4, 159-165.

Genise, J.F., Sciutto, J.C., Laza, J.H., González, M.G, Bellosi, E., 2002b. Fossil bee nests, coleopteran pupal chambers and tuffaceous paleosols from the Late Cretaceous Laguna Palacios Formation, Central Patagonia (Argentina). Palaeogeography, Palaeoclimatology, Palaeoecology 177, 215-235.

Genise, J.F., Melchor, R., Bellosi, E., González, M., Krause, M., 2007. New insect pupation chambers (Pupichnia) from the Late Cretaceous of Patagonia (Argentina). Cretaceous Research 28, 545-559.

Genise, J.F., Melchor, R.N., Bellosi, E.S., Verde, M., 2010. Invertebrate and vertebrate trace fossils in carbonates. In: Alonso-Zarza, A.M., Tanner, L. (Eds.), Carbonates in Continental Settings. Developments in Sedimentology, 61. Elsevier Publishing Group, Amsterdam, pp. 319-369.

Genise, J.F., Bellosi, E.S., Verde, M., González, M., 2011. Large ferruginised palaeorhizospheres from a Paleogene lateritic profile of Uruguay. Sedimentary Geology 240, 85-96.

Hay, R.L., Reeder, R.J, 1978. Calcretes of Olduvai Gorge and the Ndolanya Beds of northern Tanzania Sedimentology 25, 649-673.

Hay, R.L., Wiggins, B., 1980. Pellets, ooids, sepiolite, and silica in three calcretes of the southwestern United States. Sedimentology 27, 559-576.

Hernández-Pacheco, E., 1909. Estudio geológico de Ianzarote y de las Islas Canarias. Memorias de la Real Sociedad Española de Historia Natural 6, 107-342.

Hoernle, K., Carracedo, J.C., 2009. Canary Islands geology. In: Gillespie, R., Clague, D.A. (Eds.), Encyclopedia of Islands. University of California Press, Berkeley, California USA, pp. 133-143.

IGME, 2005. Mapa Geológico de España escala 1:100.000, hoja y memoria $n^{\bullet} 88$ Lanzarote. $1^{a}$ edición. Madrid.

IGME, 2006. Mapa Geologico de España, escala 1: 100.000 , hoja y 918 memoria n 92 Fuerteventura. $1^{\text {a }}$ edición. Madrid.

Johnston, P.A, Eberth, D.A. Anderson, P.K., 1996. Alleged vertebrate eggs from Upper Cretaceous redbeds, Gobi Desert, are fossil insect (Coleoptera) pupal chambers: Fictovichnus new ichnogenus. Canadian Journal of Earth Sciences 33, 511-525.

Klappa, C.F., 1980. Rhizoliths in terrestrial carbonates: classification, recognition, genesis and significance. Sedimentology 27, 613-629.

Ia Roche, F., Genise, J.F., Castillo, C., De Ia Nuez, J., Quesada, M.L, García, C., 2010. Presencia de Palmiraichnus castellanosi (Roselli 1939) en las Islas Canarias (España). Resúmenes del Primer Simposio Iatinoamericano de Icnología, Sảo Ieopoldo, p. 44.

Iea, A.M., 1925. Notes on some calcareous insect puparia. Records of the South Australian Museum 3, 35-36.

Machado, A, 1976. Introduction to a faunal study of the Canary Islands laurisilva, with special reference to ground beetles. In: Kunkel, G. (Ed.), Biogeography and Ecology in the Canary Islands. W. Junk, The Hague, pp. 347-411.

Mas, G., Ripoll,J., 2010. Cambres de pupació d'insectes coleòpters del Pliocè-Pleistocè inferior de Mallorca (Illes Balears, Mediterrảnia occidental). Significació paleoambiental i cronoestratigràfica: Bolletí de la Societat d'Història Natural de les Balears, 53 , pp. 91-105.
Meco, J., 2008. Historia Geológica del clima en Canarias. In: Meco, J. (Ed.), International Union of Geological Sciences, Unesco and ULPGC, Ias Palmas de Gran Canaria, 296 pp

Meco, J., Petit-Maire, N., Ballester, J., Betancort, J.F., Ramos, A.J.G., 2010. The Acridian plagues, a new Holocene and Pleistocene palaeoclimatic indicator. Global and Planetary Change $72,318-320$.

Meco, J., Muhs, D.R., Fontugne, M., Ramos, A J.G., Lomoschitz, A., Patterson, D., 2011. Late Pliocene and Quatemary Eurasian locust infestations in the Canary Archipelago. Iethaia $44,440-454$

Meléndez, A, Alonso-Zarza, AM., Sancho, C., 2011. Multi-storey calcrete profiles developed during the initial stages of the configuration of the Ebro Basin's exorrheic fluvial network. Geomorphology 134, 232-248.

Mikuláš, R., Genise, J.F., 2003. Traceswithin traces. Holes, pits and galleries in walls and fillings of insect trace fossils in paleosols. Geologica Acta 1, 339-348.

Millière, L, Hasinger, O., Bindschedler, S., Cailleau, G., Spangenberg, J.E., Verrecchia, E.P., 2011. Stable carbon and oxygen isotopic signatures of pedogenic needle fibre calcite. Geoderma 161, 74-87.

Oromí, P., Machado, A. Zurita, N., García, A., Martín, E., 2004 Coleoptera. In: Izquierdo, I., Martín, J.L, Zurita, N., Arechavaleta, M. (Eds.), Lista de especies silvestres de Canarias (hongos, plantas y animales terrestres). Consejería de Medio Ambiente y Ordenación Territorial. Gobierno de Canarias, pp. 208-247.

Petit-Maire, N., Rosso,J.C., Delibrias, G., Meco, J., Pomel, S., 1987. Paléoclimats de l'île de Fuerteventura (Archipel Canarien). Palaeoecology of Africa 18, 351-356

Retallack, G.J., 2001. Soils of the Past(2nd Edition). Blackwell, Oxford (404 pp.).

Roselli, F.L, 1987. Paleoicnología. Nidos de insectos fósiles de la cubertura Mesozoica del Uruguay: Publicaciones del Museo Municipal de Nueva Palmira, 1, pp. 1-56.

Rothe, P., 1986. Kanarische Inseln. Sammlung Geologische Führer 81, 1-226.

Sacchi, E., Petti, M., 2008. Insect pupation chambers from the Pleistocene paleosols of Santo Stefano Island (Pontine Archipelago, Central Italy). Studi Trentini di Scienze Naturali, Acta Geologica 83, 205-210.

Sánchez, MV., Iaza, J.H., Bellosi, E.S., Genise, J.F. 2010. Ichnostratigraphy of middle Cenozoic Coprinisphaer from central Patagonia: insights into the evolution of dung beetles, herbivores and grass-dominated habitats. Palaeogeography, Palaeoclimatology, Palaeoecology 297, 633-648.

Schmincke, H.U., Klüegel, A, Hasteen, T.H., Hoernle, K., Van der Bogaard, P., 1998. Samples from the Jurassic ocean crust beneath Gran Canaria, La Palma and Ianzarote (Canary Islands). Earth and Planetary Science Letters 163, 343-360.

Steiner, C., Hobson, A., Favre, P., Stampfli, G., Hernández, J., 1998. Mesozoic sequence of Fuerteventura (canary Islands): witness of Early Jurassic sea-floor spreading in the central Atlantic. Bulletin of the Geological Society of America 110, 1304-1317.

Verrecchia, E.P., Verrecchia, K.E., 1994. Needle-fiber calcite: a critical review and a proposed classification. Journal of Sedimentary Research 64, 650-664.

Verrecchia, E.P., Freytet, P., Verrecchia, K.E., Dumont, J.L., 1995. Spherulites in calcrete laminar crusts: biogenic $\mathrm{CaCO}_{3}$ precipitation as a major contributor to crust formation. Journal of Sedimentary Research 65, 690-700.

Verrecchia, E.P., Braissant, O., Cailleau, G., 2006. The oxalate-carbonate pathway in soil carbon storage: the role of fungi and oxalotrophic bacteria. In: Gadd, G.M. (Ed.), Fungi in Biogeochemical Cycles. Cambridge University Press, pp. 298-310.

Vogt, T., 1984. Croûtes calcaires: types et genèse. Dissertation Thèse, Univ. Iouis Pasteur, Strasbourg, $239 \mathrm{pp}$

Von Suchodoletz, H., Kühn, P., Hambach, U., Dietz, M., Zöller, L, Faust, D., 2009. Loess like and palaeosol sediments from Ianzarote (Canary Islands / Spain) - indicators of palaeoenvironmental change during the Iate Quaternary. Palaeogeography, Palaeoclimatology, Palaeoecology 278, 71-87.

Zazo, C. Hillaire-Marcel, C., Goy, J.L., Ghaleb, B., Hoyos, M., 1997. Cambios del nivel del mar-clima en los últimos 250 ka (Canarias Orientales, España). Boletín Geológico y Minero $108,487-497$

Zazo, C, Goy, J.L, Hillaire-Marcel, C, Gillot, P.Y., Soler, V., González,J.A., Dabrio, C.J, Ghaleb, B., 2002. Raised marine sequenœes of Ianzarote and Fuerteventura revisited-a reappraisal of relative sea-level changes and vertical movements in the eastern Canary Islands during the Quaternary. Quatemary Science Reviews 21, 2019-2046.

Zhou, J., Chafetz, H.S., 2009. Biogenic caliches in Texas: the role of organisms and effect of climate. Sedimentary Geology 222, 207-225. 